\title{
Investigation of the Effect of Peer-Led Team Learning Model on University Students' Exam Achievement in General Chemistry
}

\author{
Ece N. EREN ŞIŞMAN*a, Ceyhan ÇİGDEMOĞLU ${ }^{\mathrm{b}}$, Ömer GEBAN ${ }^{\mathrm{c}}$
}

\begin{tabular}{l} 
Article Info \\
\hline DOI: $10.14686 /$ buefad.412614 \\
\hline Article History: \\
Received: $\quad 04.04 .2018$ \\
Accepted: $\quad 17.05 .2018$ \\
Published: $\quad 30.06 .2018$ \\
\hline Keywords: \\
Peer-led team learning, \\
General chemistry, \\
Chemistry workshop, \\
Engineering students. \\
\hline Article Type: \\
Research Article
\end{tabular}

\begin{abstract}
The purpose of this study was to compare freshmen engineering students' exam achievement in general chemistry course using peer-led team learning model and traditional instruction and to investigate the effect of this model on different achieving level students. A total of 128 students who were instructed by the same professor participated in the study. Throughout the semester, Peer-Led Team Learning (PLTL) model was implemented in the experimental group while traditional instruction was used in the control group. 14 peer leaders who have successfully completed general chemistry course in previous semester have been trained on basic communication and pedagogy issues and they have supported their teams in problemsolving. Both experimental and control group students took the same mid-terms and final exam. The data were analyzed by two-way analysis of variance (ANOVA). Consequently, although there was no statistically significant main effect of teaching methods, due to statistically significant interaction effect, it was found that low and medium achievers' general chemistry exam grades were statistically higher in PLTL group than those of traditional group; however, there was no statistically significant mean difference in high achievers' grades between PLTL and traditional instruction groups.
\end{abstract}

\section{Akran-Liderliğinde Takım Öğrenmesi Modelinin Üniversite Öğrencilerinin Genel Kimya Sınav Başarısı Üzerindeki Etkisinin İncelenmesi}

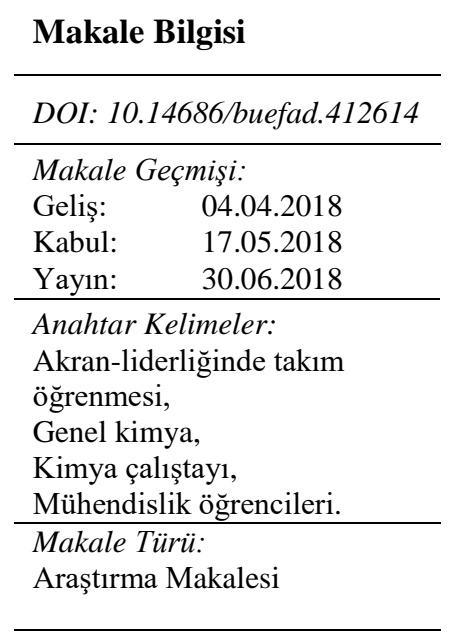

\section{$\ddot{O} \mathbf{z}$}

$\mathrm{Bu}$ çalışmanın amacı, mühendislik fakültesi birinci sınıf öğrencilerinin genel kimya ders başarısını akran liderliğinde takım öğrenmesi modeli ve geleneksel öğretim modeli kullanılan durumlarda karşılaştırmak ve yöntemin farklı başarı seviyelerindeki öğrenciler üzerinde etkisini incelemektir. Çalışmaya aynı öğretim üyesinin okuttuğu toplam 128 öğrenci katılmıştır. Deney grubu bir dönem boyunca Akran Liderliğinde Takım Öğrenmesi (ALTÖ) modeli ile ders yaparken kontrol grubunda geleneksel öğretim uygulanmıştır. Daha önceden bu dersi başarı ile tamamlamış 14 takım lideri dönem boyunca hem temel iletişim ve pedagoji konularında eğitilmiş, hem de takımlarına problem çözme konusunda destek olmuştur. Deney ve kontrol grubu aynı ara sınavlara ve final sınavına girmiştir. Veriler iki yönlü varyans analizi (two-way ANOVA) ile incelenmiștir. Sonuç olarak, her ne kadar öğretim yöntemlerinin istatistiksel olarak anlamlı bir etkisi olmasa da, istatistiksel olarak anlamlı çıkan ortak etki faktörüne bağlı olarak, düşük ve orta düzey başarılı öğrencilerinden ALTÖ modeliyle öğretim alanların geleneksel öğretim alan gruba göre genel kimya sınav başarı notlarının istatistiksel olarak daha iyi olduğu bulunmuş, ancak ALTÖ modeli ve geleneksel öğretim gruplarındaki yüksek başarılılar karşılaştırıldıklarında genel kimya başarıları açısından bir farklılık olmadığı saptanmıştır.

\footnotetext{
*Corresponding Author: neren@metu.edu.tr

${ }^{a}$ Res. Asst., Middle East Technical University, Ankara/Turkey, http://orcid.org/0000-0002-1003-0612

${ }^{\mathrm{b}}$ Asst. Prof. Dr., Atılım University, Ankara /Türkiye, http://orcid.org/0000-0001-5389-5790

${ }^{c}$ Prof. Dr., Middle East Technical University, Ankara/Turkey, http://orcid.org/0000-0002-9433-0056
} 


\section{Introduction}

School dropout rates among university students in the first years are very high (Barefoot, 2004) and one of the most important reasons for this is their failure (Şimşek, 2013). Personal factors and school factors are likely to rise failure thus that causes an increase in dropout rates of courses and schools (Peters, 1992). Dropout is one of the key barriers to success in first-year introductory courses such as science, technology, engineering, and mathematics (STEM) at the university level. For this reason, it is necessary to focus on comprehensive programs that have the potential to increase students' achievement, interest and belonging in such courses. According to Tinto (1975), one way of doing this is to develop new teaching models in which students will feel a sense of belonging to an academic society. Additionally, according to Tobias (1992), mentoring relationships are crucial for students' success and careers, and traditional teaching approaches fail to emphasize these aspects. Besides, traditional instruction sometimes lacks in the construction of scientific investigations over pre-conceptions, and development of these investigations through strong discussions and arguments. In this context, peer-led team learning (PLTL) has become a widely accepted and practiced teaching model in the STEM field. PLTL is also perceived as a model that can overcome the above-mentioned problems because in this model students participate actively in scientific discussions. This is closely related to students' learning, and achievements.

\section{Peer-Led Team Learning (PLTL) Model}

PLTL model was formerly introduced by David Gosser in a General Chemistry course at the City College of New York (CCNY) in the early 1990s and has been implemented and disseminated through support of the National Science Foundation to address faculty concerns about student learning and high attrition rates in chemistry, biology, physics, mathematics and computer science as well as engineering courses in many colleges and universities in the United States (Gafney \& Varma-Nelson, 2008; Goodwin, 2002).

PLTL model does not require the instructors to change both their routine in the course or their teaching methods. Varma-Nelson (2006, p.19) states that "the PLTL model preserves the lecture and introduces a new structure, a weekly two-hour workshop". The core of the issue is creating well-organized and supportive study groups so it is recommended that one hour of the course will be replaced by this peer-led workshop (Gafney \& Varma-Nelson, 2008). Accordingly, PLTL can be defined as a structured form of team learning which a small group of six to eight students meets weekly under the guidance of a peer leader to discuss and solve a set of carefully developed problems in accordance with lecture topics in an active learning environment (Gafney \& Varma-Nelson, 2008; Varma-Nelson, Cracolice \& Gosser, 2004). Another feature of this model is the specific role of a peer leader who is competent in both chemistry and communication. They are generally selected among the undergraduate students who have recently completed the course successfully with a high grade (A or B) and demonstrated leadership potential and strong interpersonal and communication skills. (Gafney \& Varma-Nelson, 2008). In the PLTL workshops, students work together to reach a solution of the problem while peer leaders give advice about the resources, thinking patterns and process (Crocolice \& Deming, 2001). Besides, peer leaders facilitate a discussion among the students in a group to interact with one another, promote brainstorming and encourage them to solve and discuss the structured problems (Gosser et al., 2001). According to Varma-Nelson and Coppola (2005), since students aim to find and evaluate several possible solutions in the PLTL workshops rather than learn a single correct answer, the answer keys should not be provided to the students or the leaders.

The role of the instructor in PLTL model is to prepare workshop materials as well as choose and train the peer leaders for their courses (Gosser et al., 2001). Peer leaders come together with course instructors to discuss the concepts and workshop materials each week. In addition, the content of workshop should be consistent with the lecture hour weekly schedule. Moreover, workshop materials should be carefully constructed not only to address common misconceptions and to develop conceptual understanding in chemistry concepts (Varma-Nelson et al, 2004) but also to promote the collaboration, interaction, and active engagement with individuals in groups (Gosser $\&$ Roth, 1998). As a result, students are able to develop their conceptual understanding and learn to communicate scientific ideas in a social community. (Gosser \& Roth, 1998; Gosser et al., 1996; Sarquis et al., 2001; VarmaNelson et al., 2004).

\section{Theoretical Background}


PLTL model is grounded on a socio-cognitive theory which emphasizes active participation of individuals. The theoretical framework behind this model also includes the social learning theory of Vygotsky (1987). Furthermore, the constructivist approach, in which "students' learning is structured by taking active roles in individual and social processes" (National Research Council, 1996, p. 28), is base for the theoretical framework of the model. According to Driver, Newton, and Osborne (2000), small teams in this model are perceived as scientific communities that support knowledge construction through social processes between individuals. PLTL workshops offer students with an active and collaborative learning environment by providing opportunities for discussion, reconciliation, knowledge construction, presenting what they understand, and hearing their peers' views. In solving the problems, students interact with each other to transform their experience into useful knowledge through sharing, evaluating, and refining their ideas (Brown and Campione, 1994; Brown, Collins \& Duguid, 1991; Roschelle, 1992). Conceptual learning in the classroom environment is dependent on the ability of the person to communicate with peers and to build and reconstruct knowledge through social processes (Driver et al., 2000). In other words, comprehension of knowledge evolves by communicating and interacting with others. Hence, teaching models based on the idea that knowledge is created through social processes have wide implications (Brown et al., 1991). PLTL also allows peer interaction such as "sharing, clarifying, and distributing knowledge among peers." as one of these models (Rivard \& Straw, 2000, p.585). Another key process observed in student' discussion in this model is the "connected discourse" in which the details of the exchange between students' ideas are observed through a complex reasoning. These and similar processes provided by the peer-led team learning environment have great potential to construct meaningful knowledge.

The main element of many student-centered learning environments is facilitating and promoting student interaction by a peer. This learning environment proposes individuals' to exceed their zone of proximal development. According to the social learning theorist Vygotsky (1978, p.86), the zone of proximal development is defined as "the distance between the actual developmental level as determined by independent problem solving and the level of potential development as determined through problem-solving under adult guidance, or in collaboration with more capable peers". Another positive aspect of student-centered approaches is that students help each other in the learning of conceptually rich course material and support their zone of proximal development. Since in the PLTL model the peer leader is equal or much more close to student's zone of proximal development level compared to the course instructor, s/he has a chance to interact with students through different ways in which instructor does not have. In addition, the high experience of the peer leader on the course and the content knowledge, which students do not have, provide a critical role in encouraging peers' interaction and exchanging the ideas among students. Peer leaders undertaking such role try to encourage participation, support the autonomy of all students in his/her team.

As included in cooperative learning, PLTL model incorporates the elements of working together to achieve a common purpose (Johnson \& Johnson, 1999, Johnson, Johnson, \& Smith, 1991). Peer-led team learning integrates positive interdependence and face-to-face interaction while at the same time supporting small group work and individual accountability through a more knowledgeable and experienced peer leader. The ability of the classmates to express what they understand can be exemplified as individual accountability. In this model, the teaching of basic skills to students develops through communication and interaction throughout the process rather than a formal process. Beyond those, all students; women, men, minorities, foreign nationals can reasonably participate in and benefit from such a collaborative learning environment.

\section{PLTL Implementations in General Chemistry Course}

A body of research shows that student-centered pedagogies are more effective on student performance than traditional pedagogies because they provide students with the opportunity to build dependent learning communities (Irvine, Code \& Richards, 2013; Tutty \& Klein, 2008). The effectiveness of the PLTL model, as one of the high impact teaching models, over students, leaders, instructors, and institutions has been measured and evaluated in many learning environments (Ba'ez-Galib, Colon-Cruz, Resto, \& Rubin, 2005; Hockings, DeAngelis, \& Frey, 2008; Lewis \& Lewis, 2005; Lyon \& Lagowski, 2008; Tien, Roth, \& Kampmeier, 2002), and it has been shown that the model is sucessessful in many STEM disciplines (Hockings et al., 2008; Lewis 2011; Lyle \& Robinson 2003; Lyon \& Lagowski 2008; Preszler 2009; Tien et al., 2002; Wamser 2006). Since the PLTL was first implemented in chemistry, the majority of the conducted studies has been done in this area, especially conducted in general chemistry (Alger \& Bahi, 2004; Ba'ez-Galib et al., 2005; Chan \& Bauer, 2015; Drane, Micari, \& Light, 2014; Mitchell, Ippolito, \& Lewis, 2012), organic chemistry (Lyle \& Robinson, 2003; Tien et al., 2002), biology 
(Prezler, 2009), mathematics and engineering (Liou-Mark, Dreyfuss, \& Young, 2010; Loui-Mark \& Robbins, 2008) and the findings support the success of the model. In other words, students in the PLTL group receive higher grades (Hockings et al., 2008) and learning in these students has higher retention rate (Drane et al., 2014; Lewis, 2011).

Ba'ez-Galib et al. (2005) aim to make general chemistry students be successful at the undergraduate level by preparing an interactive program named Chem2Chem. They prepare a supportive learning environment in which students' positive attitudes and self-confidence are supported to meet their academic and emotional needs without compromising the quality, content, and expectations of the course. Researchers emphasize that the program they have developed has striking results on the success of students. To illustrate, between 1995 and 1997 (before Chem2-Chem was implemented), the percentages of unsuccessful students are 42-51\%, then when the program is implemented, it is dropped to $21 \%$. In addition, Hockings et al. (2008) examine the effect of the PLTL model on student achievement by using it with traditional course structure. The results show that the model satisfies the needs of the faculty and students, presenting the model as a compulsory part of the course is suitable for a traditional university structure, and the students compulsorily participate. When the performances of the secondsemester students who have taken the general chemistry course again with the PLTL model is compared to the performance of the first semester PLTL students, almost a one-third positive difference is observed in favor of the second semester PLTL students. Mitchell et al. (2012) study on general chemistry courses that last two semesters and examine students' attendance on second semester PLTL implementation. They find that they do not increase student achievement with single-semester practice.

When examining the study of Lewis and Lewis conducted in 2005 at the undergraduate level chemistry, it is seen that they form peer-led groups in the general chemistry course and evaluate how the model impacts students' understanding. They conduct an experimental study, one group of the same instructor is an experimental group, and the other is the control group. Comparing students' midterm and final exam grades of experimental and control groups reveal that peer-led group students' performances significantly differ in favor of them. In another study, Lewis (2011) fully evaluates the PLTL model by examining the performance of university freshman students who have enrolled in a general chemistry course. By preserving the normal course duration, PLTL is implemented in approximately one-third of the course time, and the results are compared with the groups performing traditional teaching.Consequently, it is found that the experimental groups show a statistically significant improvement compared to the traditional groups by $15 \%$, and the retention of subjects is found to be higher in the experimental groups. In addition, the researcher finds that minority students in the PLTL groups have higher course passing rates than minority students in the control groups. McCreary, Golde, and Koeske (2006) implement PLTL model in the laboratory of the general chemistry course with experimental and control groups and examine the impact of the model. Both from the content analysis of students' written exam responses and other qualitative data, they conclude that students in PLTL workshops have a higher performance than the other groups.

According to Amaral and Vala (2009), who perform the PLTL model in the first year general chemistry course at the undergraduate level, examine the effects of the model on mentor students' (peer leaders) successes and their retention. The performances of students who attend and do not attend the mentoring program (training) were compared. As a result, students who have participated in the mentoring program have a higher average than the other students and it is reported that the course withdraws rates are much lower even if less effort is made. Based on another study related to long-term effects of the PLTL experience on peer leaders conducted by Gafney and Varma-Nelson (2007), peer leaders both improve their performance and acquire some personal gains such as being much more confident and having advanced team-related skills. One more study on peer leaders is conducted by (2009) who have investigated whether peer leaders selected from the previous years or peer leaders selected from within the class will be more effective. They find out no difference between in-class peer leaders and peer leaders selected from the previous year. They also interpret that two different leader groups have a different role; standard peer leaders teach more and control their groups better, but they are not friends with peers, while the leaders selected within the class know more about their peers. When comparing the academic performances and student satisfaction levels of two different types of peer-led groups, it is discovered that both groups were completely equal. In another study conducted by Gosser (2011) compares grades of students who attend PLTL workshops and those who do not attend the PLTL workshops. The results show that $15 \%$ of the students having $\mathrm{C}$ or higher grades are in favor of the students who attend these workshops.

As seen from the literature review, the model has an inevitable effect on students' performance. However, the research regarding how low achievers, moderate achievers and high achievers benefit from PLTL model is 
insufficient. Having no comprehensive research on PLTL in Turkey, along with acquiring no information about the effectiveness of the model for students with different sachievement level makes it attractive to conduct a research study. The aim of this study is to examine the impact of the method on freshman engineering students' exam achievement in general chemistry at a private university in Turkey. By investigating how the success of the students in different achievement groups will be influenced by the implementation, the study proposes to contribute to the PLTL literature. The main research question is what is the effect of teaching methods (PLTL model and Traditional instruction) and achievement levels (low, moderate and high) on freshman engineering students' exam achievement in general chemistry. The sub-questions are as follows:

1. Is there a statistically significant difference in general chemistry exam achievement scores of freshman engineering students instructed with PLTL model between those instructed with traditional instruction?

2. Is there a statistically significant effect of freshman engineering students' achievement levels (low, moderate and high) on their general chemistry exam scores?

3. Is there a statistically significant difference in the effect of freshman engineering students' achievement levels on their general chemistry exam achievement scores for teaching methods (PLTL model and Traditional instruction)?

\section{Methodology}

\section{Research Design}

The purpose of this study is to examine the effect of the peer-led team learning on undergraduate engineering students' academic achievement in General Chemistry. The quasi-experimental method of experimental research designs was used in this study. In educational studies, it is difficult to conduct a study with the true experimental design because selecting students or classes randomly is usually impossible in the institutions, thus, in the most of the experimental research quasi-experimental design is used (Fraenkel \& Wallen, 2006). Therefore, in the current study experimental and control groups are randomly selected from two sections of the course instructed by the same professor. As seen from Table 1, the experimental group was treated with peer-led team learning (PLTL) model for one semester, while the control group was treated with traditional instruction, both groups have taken two midterms and a final exam at the same time.

Table 1. Research Design

\begin{tabular}{lcccccc}
\hline Groups & Implementation & Mid-Term 1 & Implemantation & Mid-Term 2 & Implemantation & Final \\
\hline CG & TI & MT & TI & MT & TI & F \\
EG & PLTL & MT & PLTL & MT & PLTL & F \\
\hline
\end{tabular}

Note: CG: Control group, EG: Experimental group, PLTL: Peer-led team learning, TI: Traditional instruction, MT: Mid-term, F: Final exam

\section{Sample}

The sample of this study which was selected conveniently consisted of 128 freshmen engineering students enrolled in general chemistry (CEAC 105) course at Attlım University. 60 (47 male and 13 female) of the participants were in control group (CG) and 68 (53 male and 15 female) of them were in experimental groups (EG), the instructor was the same for both groups. The participants of the experimental group were the students who attended at least $50 \%$ of the PLTL workshops. The age range of the students is around 19. The number of students in each achievement level was also presented for CG and EG in Table 2. 
Table 2. The Comparison of Frequency and Percentage of Students instructed by Traditional Instruction and PLTL Model in Terms of Student Achievement Levels

\begin{tabular}{lcccccc}
\hline Achievement & \multicolumn{4}{c}{ Teaching methods } & \multicolumn{2}{c}{ Total } \\
& \multicolumn{2}{c}{ Traditional instruction } & \multicolumn{2}{c}{ PLTL model } & & \\
& $\mathrm{N}$ & Percent & $\mathrm{N}$ & Percent & $\mathrm{N}$ & Percent \\
\hline Low-achievers & 13 & 21.8 & 25 & 36.8 & 38 & 29.7 \\
Moderate-achievers & 31 & 51.6 & 27 & 39.7 & 58 & 45.3 \\
\hline High-achievers & 16 & 26.6 & 16 & 23.6 & 32 & 25 \\
Total & 60 & 100 & 68 & 100 & 128 & 100 \\
\hline
\end{tabular}

When total percent values of both groups were examined in Table 2, it was seen that the highest percentage was in "Moderate-achievers" category with $45.3 \%$, followed by the "Low-achievers" category with $29.7 \%$, and then followed by the "High-achievers" category with $25 \%$. While this general pattern was recognized from percent values of both total and PLTL model, it was seen that the percentage of high achievers (26.6) were higher than that of low achievers (21.8) in traditional instruction.

In addition, 14 students were selected as peer leaders from the individuals who have attended General Chemistry previously and completed it successfully. Purposive sampling was used to select peer leaders because peer leaders should have some requirements and characteristics for the proper implementation of the PLTL workshops. For example, leaders must be successful students (B grade or better) from the previous year's course and have some skills in leadership, communication, and group work. A voluntary participation and informed consent form has been applied to the students and leaders who participated in the study.

\section{Data Collection Tools}

General chemistry exam achievement score. Students' exam scores would show their achievements in the general chemistry course in this study. In general chemistry course, there were two midterm exams conducted in the semester and one final exam conducted at the end of the semester, and both had 20 multiple choice questions. In those, each correct answer was 5 points, and the incorrect answer was considered as 0 points and the total points that a student could take from any exam range between 0 and 100 points. In addition, the content included in these exams was shown in Table 5, chapters 6, 7, 8, 9, 10 were included in the first midterm, chapters 11,12, 5,19 were included in the second midterm, and the whole chapters were covered for the final exam. These exams were prepared by the professors of the course together. Additionally, students' grades were calculated based on their exam scores, and the percentages of these exams were provided in Table 3.

Table 3. The Percentage of Exams on General Chemistry Grades

\begin{tabular}{lc}
\hline Exams & Percentage \\
\hline Mid-term I & $30 \%$ \\
Mid-term II & $30 \%$ \\
Final exam & $40 \%$ \\
\hline
\end{tabular}

Achievement levels (University placement scores-MF-4). From the 2011 - 2012 academic years, the university examination system that is held every year by the Center for Measurement, Selection and Placement (ÖSYM) takes place in two steps as YGS (Higher Education Entrance Exam) and LYS (Bachelor Placement Examinations). While YGS is a general test based on the common curriculum of all courses, LYS is a collection of branch tests based on measuring the success of each course. There are 6 different types of scores for YGS (YGS-1-2-3-4-5-6), and 12 different scores types for LYS [MF-1-2-3-4 (Mathematics-Science), TM-1-2-3 (Turkish Language and Literature-Mathematics), TS-1-2 (Turkish Language and Literature-Mathematics- Social Sciences), and LANG1-2-3 (Foreign Languages)]. In YGS and LYS, the minimum score is 100 and the maximum score is 500. Students' placement to engineering faculties is made according to MF-4 (Mathematics-Science) scores. If students want to select an engineering department, s/he must take YGS, LYS-1 (Mathematics) and LYS-2 (Physics, Chemistry, and Biology) tests in order to be placed in one of these undergraduate engineering programs. Then, based on these test scores, ÖSYM calculate students' overall MF-4 scores. The university entrance scores of students enrolled in a general chemistry course for the 2015-2016 academic year were obtained from At1lim University students' affairs unit. The MF-4 score range of the students is between 209 and 390.65. The average of these scores is 295.10, and 
the standard deviation is calculated as 39.75. MF-4 scores were transformed into categorical forms as low, medium, and high achievement levels, and the frequency values were shown in Table 4.

Table 4. Cumulative Relative Frequency Table Based on Categorical Classification of Students' MF-4 Scores

\begin{tabular}{lccccc}
\hline Categories & $\begin{array}{c}\text { LL-HL } \\
\text { (Scores range) }\end{array}$ & $\begin{array}{c}\text { Frequency } \\
(\mathbf{N})\end{array}$ & $\begin{array}{c}\text { Relative } \\
\text { Frequency } \\
(\boldsymbol{\%})\end{array}$ & $\begin{array}{c}\text { Cumulative } \\
\text { Frequency } \\
(\mathbf{N})\end{array}$ & $\begin{array}{c}\text { Cumulative } \\
\text { Relative } \\
\text { Frequency }(\%)\end{array}$ \\
\hline Low-achievers & $<270.00$ & 46 & 36 & 46 & 36 \\
Moderate-achievers & $270.00-319.99$ & 50 & 39 & 96 & 75 \\
High-achievers & $320.00>$ & 32 & 25 & 128 & 100 \\
Total & & 128 & 100 & & \\
\hline
\end{tabular}

Note: LL: Low limit, HL: High limit, N: Number of students.

\section{Treatments}

\section{PLTL Model}

In this section, the treatment performed for 14 weeks in the experimental group was introduced. In this study, six PLTL workshops were organized biweekly by taking one lecture hour of the course, which was three lecture hours per week. In the other weeks, students attended three lecture periods. Leaders came to the study hall for the workshop with their peers, and they formed a cluster-like seating arrangement in a part of the class. Peer leaders wore an identification card and talked with peers with their names. Students participated in each workshop with a booklet which was prepared for the implementation and given to them beforehand. In the first 10 minutes, peer leaders have identified their difficulties related to individual review problems and summarized the key points about concepts. After that, they discussed the team learning problems in the booklet by using the teaching techniques taught in the leader training sessions. Students were given time to solve and analyze the questions, and then guide them to the solutions through the hints about how to solve the problems by asking questions to the students. They made inferences by means of the feedback from peer leaders and interactions with peers. Leaders have been checked whether all members of the team understood the solutions of the problems within the given time. After they covered team problems, a test consisting of one or two questions was given to the students to solve individually. Since the students discussed and learned how to explain the team problems within their teams, they were able to solve these questions individually. Problems that could not be answered in this test were taken as evidence that the content was not well understood and thus, necessary feedbacks were provided to the students by the leaders.

To enhance treatment fidelity and verification, the instruction used for PLTL group were defined explicitly with the help of the literate and then theoretical framework for the model. Thus, the handbook about the implementation of PLTL study (Gosser et al., 2001) was taken as a guideline and six critical components proposed by Gafney (Gafney \& Varma-Nelson, 2008) were followed as the basis for the intervention. These six critical components of the PLTL model; departmental support, integral to the course, institutional/organizational arrangements, administrative support, preparation of course materials, selection of peer leaders, and their training were briefly described in the following sections. Besides, Figure 1 collectively indicates the processes included these components before and during the implementation. They also had a great importance for defining, effectively implementing, and evaluating the PLTL model as well as discriminating it from other related student-centered methods and if it was implemented properly based on these components, one might expect a noticeable increase in students' performances (Gafney \& Varma-Nelson, 2008).

Departmental support. The first step for successful implementation of the PLTL model is the acquisition of departmental support. For this, the faculty members offering general chemistry at the Department of Chemical Engineering and Applied Chemistry were informed, and they are requested to give support for the changes to be made within the scope of the research. The course instructor has voluntarily cooperated throughout the PLTL workshops during implementations. She reviewed the materials, provided feedback, and made some revisions.

Integral to the course. It is important to integrate and coordinate PLTL to the course as if it is a component of it (like; theoretical course hours, laboratory, recitation). For this reason, the PLTL workshops were compulsory for the students as for the other parts of the course such as the laboratory. During these workshops, individual 
quizzes were held and attendance was taken. General chemistry has three 50 minutes course duration per week. Within the scope of the study, one of the 50 min parts will be advocated as workshop session. Gafney and VarmaNelson (2008) expressed that the optimum time for an effective workshop should be 90 to 120 minutes. For this reason, the 50 minutes duration has been increased to 75 minutes provided that it is suitable for students program. The contents of the PLTL workshops were parallel with the topics covered at that week.

Institutional/organizational arrangements, and administrative support. In order to run weekly PLTL workshops without disruption, it is necessary to allocate suitable learning environment for group work, also, available places for leader training should be arranged. For this reason, a study hall in the faculty of engineering has been determined and required permissions have been obtained from the administrative units. Besides, when additional staff and materials, such as tables, chairs, etc that may be needed have been rearranged according to the number of students in each workshop. The peer leaders' training hours and their participation in the workshops were arranged based on their weekly schedule.

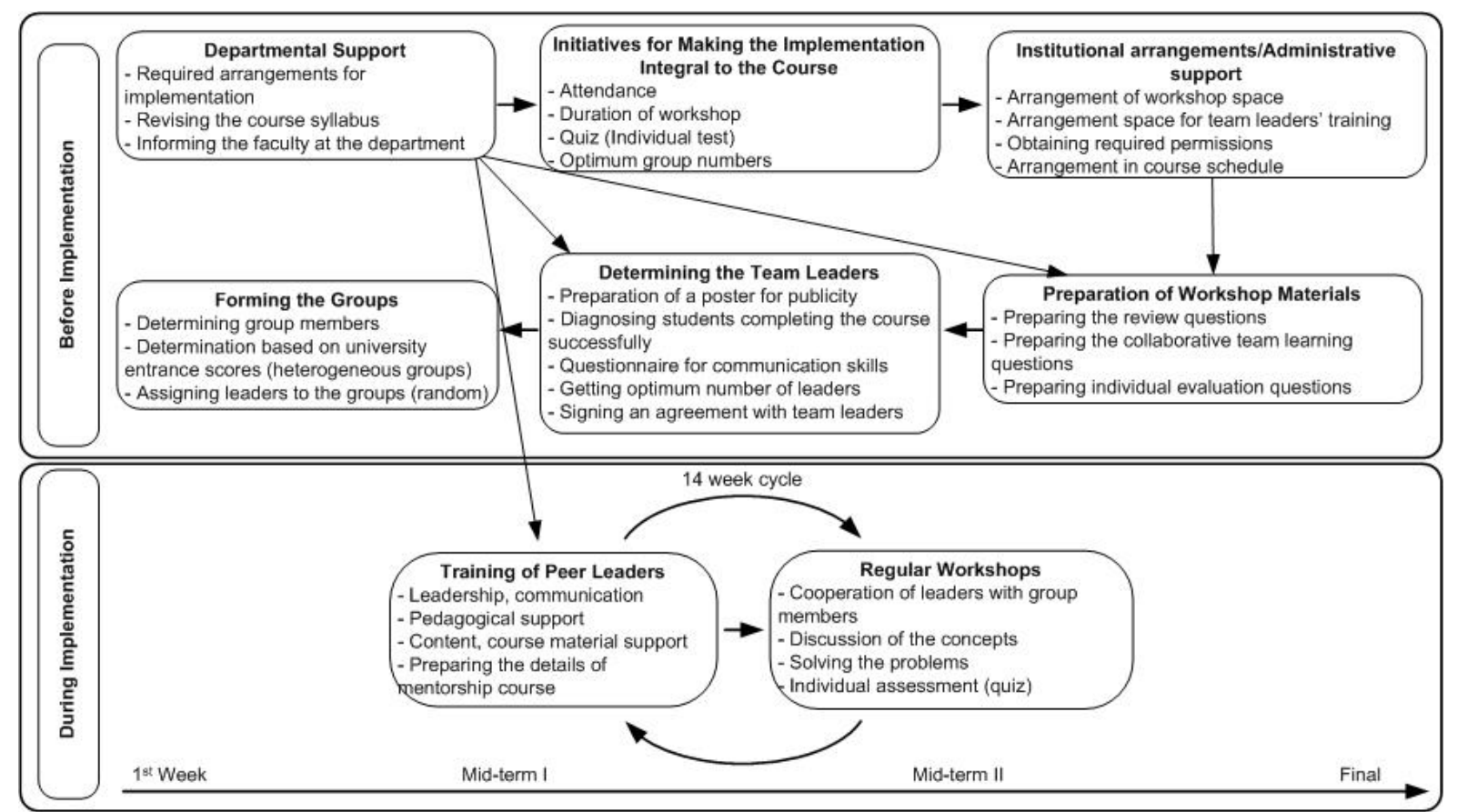

Figure 1. Schematic Representation of Steps for PLTL Model

Preparation of workshop materials. The General Chemistry (CEAC 105) course at Atılim University has 3 course hours in each week, 3 hours of laboratory within two weeks, and it is a 5 ECTS credits course, the course is a must course for all engineering departments' students except for chemical engineering and applied chemistry and metallurgy and material engineering departments. Engineering students take this course in one semester. The content of the course and related chapter numbers and estimated course hours based on the chapters of the course book (Brown et al, 2015) are shown in Table 5. The course covers selected chapters from the book.

Based on the chapters given in Table 5, course materials were prepared at the beginning of the semester for each workshop. In this process, researchers carefully prepared the problems that will be solved collaboratively based on the directions provided in literature and the book "Peer-Led Team Learning A Guidebook" prepared by Gosser et al. (2001) in order to force students in appropriate level, fit with the content of the course, and encourage active and collaborative learning. In addition to this, based on the concept proposed by Vygotsky (1987), "Zone of Proximal Development" by was taken into consideration while forming the theoretical framework of questions. In this way, a booklet has been prepared for PLTL workshops including sub-topics and related course objectives for each chapter. 
Table 5. General Chemistry Course Topics and Hours

\begin{tabular}{lcc}
\hline Chapter Numbers & Topics & Estimated Lecture Hours \\
\hline 6 & Electronic Structure of Atoms & 7 \\
7 & Periodic Properties of the Elements & 5 \\
8 & Basic concepts of Chemical Bonding & 4 \\
9 & Molecular Geometry and Bonding Theories & 3 \\
10 & Gases & 5 \\
Table 5 Continuation & & 2 \\
\hline 11 & Intermolecular Forces, Liquids, and Solids \\
12 & Solid and Modern Materials & 6 \\
5 & Thermochemistry & 5 \\
19 & Thermodynamics & 5 \\
\hline
\end{tabular}

Furthermore, PLTL workshop problems in each unit consisted of three parts as shown in Figure 2: (1) individual review problems that students would have completed before joining the PLTL workshop (2) team learning problems to be solved in cooperation with the peer leaders in the PLTL workshops (3) assessment problems to be solved individually after the PLTL workshops to investigate student's understanding. In the review section, the preliminary evaluation would have conducted with multiple-choice questions that students could solve on their own about the subject of the week as a summary. Students were said to solve these problems before they came to the workshop, and then in the workshop, they discussed them quickly and continued with team problems. In the second part that they solved the questions in collaboration, team learning problems were three or four openended questions in accordance with the topic, which were appropriate for the teamwork and can be solved with the help of peer leaders. Thus, with the help of the peer leaders and social interaction between students originating from the collaborative work, it was tried to increase the potentials of the students. After that, students were given individual problems, consisting of one or two multiple choice or open-ended questions, which are similar to team learning problems in order to assess their individual performances. Students were expected to be able to solve such problems individually after group work. The difference that arises between the level of problem-solving independently without help and the level at which the individual can solve the problem after entering the social interaction with the help of the peer leader constituted their zone of proximal development. As a result, it can be inferred that PLTL model supports the materials that will enable students to explore and use their zone of proximal development in the best way.

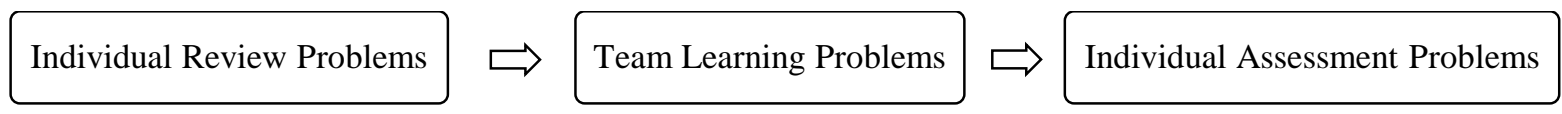

Figure 2. The Three Parts of PLTL Workshop Problems

Selection of Peer Leaders. Peer leaders must be well trained in terms of both their subject-matter knowledge, as well as communication and leadership skills. For this reason, peer leader candidates primarily were expected to have received the general chemistry course in the previous semester or the year and to have been found in the first $20 \%$ of this course. Then, interviews were conducted with these candidates and 14 students were selected considering their communication skills. After the selection of peer leaders who participated in the study, the voluntary participation form was implemented to them just like students.

Formation of Students' Teams. The size and diversity of the teams must be appropriate for efficient discussions to take place. Gafney and Varma-Nelson (2008) have been suggested six to eight students as an ideal group size and in the current study, the average size was five students per group. In order to ensure that the groups have equal opportunities, and characteristics, some demographic information such as gender, achievement level, and majors were examined are when creating the teams. To illustrate, students were divided into three groups as low, middle and high achievement levels with respect to their university entrance scores and each team included students from these three levels. In addition, a heterogeneous structure has been created by providing female students and different department students to each group. Leaders were randomly assigned to the groups by using their alphabetical name order. 
Training of Peer Leaders. Leaders were required to attend 1.5-hour training sessions, which were held eight times throughout the interventions before discussing the problems in PLTL workshops. Throughout this training, the topics in the "Peer-Led Team Learning: A Handbook for Peer Leader" written by Roth, Goldstein, and Marcus (2001) were tried to be addressed. Peer leaders were trained based on three categories; "leadership skills", "pedagogical support" and "course materials". Therefore, when team leaders gathered for training sessions, they were informed about the pedagogical knowledge and social communication as well as discuss how course materials could be solved for that week.

For the leadership skills, an academician who specialized in management gave a 2-hour training at the beginning of the term to leaders and informed them about how to communicate with their peers. The main topics of this training were impressive speaking and persuasion skills, listening skills, feedback skills, the ability to communicate positively, the timing skills in communication, and the ability to use body language effectively. Under the pedagogical support category, researchers gave leaders a brief training in every session about how they could help their peers. Those were the role of leaders, learning theories, learning styles, questioning techniques, learning differences in students, motivation, equal opportunities for everyone, race-class-gender etc. Moreover, social constructivism theory, multiple intelligence theory, collaborative learning and teaching strategies were discussed during these meetings. Leaders were expected to select and apply the appropriate teaching strategy according to the student needs in their teams and the nature of the topic. Also, they provided necessary information about how to solve the problem step by step, give them the right of speech, grant time, provide clues, and balance the needs of low achievers and those of high achievers. Course materials also constituted an important part of the training of peer leaders. During the workshop, the details of how much time they would spend on the part, the difficulties that students could encounter in solving the materials, the extra resources they could apply, and the details of the solution of the materials were discussed in these training. Peer leaders and students have not been given an answer key for the PLTL workshop problems as highlighted in the PLTL model (Varma-Nelson \& Coppola, 2005). It is very important to note that peer leaders should understand their role very well since it is necessary to act more like a guide rather than as a teacher in the PLTL workshops.

\section{Traditional Instruction}

Students in the control group attended three lecture hours of the general chemistry given by the same instructor for 14 weeks, but they did not attend the PLTL workshops. Like the lecture sessions implemented in the experimental group, she first introduced the concepts of that week and then solved some questions related to the topic. Since the one-third of the lecture hours was not allocated to the workshop in control group, the instructor had more time to solve the questions in this group.

In addition, some of the lecture hours were observed for the control group and experimental group and some field notes were taken by the researchers. In the lecture, she usually wrote the concept the board by explaining it, then solved problems herself related to concepts, asked few questions about problems and gave no time to think and analyze them. Some of the students took notes about the concept and problems while some of them only listened. There have sometimes been discussions between a few students and instructor in line with her questions. However, students generally did not ask questions and did not think deeply about the concept. The strategies used by the instructor were here mainly lecturing, questioning and sometimes discussions between a few students and teachers so it was inferred that it was predominantly teacher-centered. Finally, it was concluded that the traditional instruction was used by course instructor as intended during the study.

\section{Data Analysis}

SPSS 24 package program was used to analyze the data in this study. Data were analyzed by two-way analysis of variance (ANOVA). The reason for choosing this analysis is to simultaneously test the main effects of the factors and the interaction effect of the two factors on the dependent variable, rather than separately testing the effect of two independent variables (teaching method and achievement level) on a dependent variable (general chemistry exam achievement score). As a statistically significant interaction effect was found in the current study, one-way ANOVA was performed to report simple main effects for each achievement level. The statistical analyses were conducted at $95 \%$ confidence interval by checking the assumptions of the analyses. These assumptions are; the independence of the data (independence), the dependent variable being the continuous scale and the independent variable being the categorical scale, normality within the group (normality), and the homogeneity of the variances (homogeneity). 


\section{Results}

The findings of the study included the descriptive statistics of general chemistry exam achievement score based on teaching methods and achievement levels, two-way ANOVA to clarify whether general chemistry exam achievement can be explained statistically by the main effects or interaction effect of teaching method and achievement level factors, and one-way ANOVA to explain whether general chemistry exam achievement scores differ in terms of students' achievement levels according to the teaching methods applied in groups.

Table 6 and 7 included the mean and standard deviation values of the general chemistry exam achievement scores of freshman engineering students according to their teaching methods and achievement levels respectively. As can be seen from Table 6, according to the teaching method variable, the mean scores of the general chemistry exam achievement for students trained by traditional instruction and PLTL model were found to be 58.83 and 62.88 respectively, while the standard deviation values were found to be 16.47 and 14.71 , respectively.

Table 6. Descriptive Statistics for General Chemistry Exam Achievement Score According to Teaching Methods

\begin{tabular}{lccc}
\hline Teaching methods & $\mathbf{N}$ & Mean & SD \\
\hline Traditional & 60 & 58.83 & 16.47 \\
PLTL & 68 & 62.88 & 14.71 \\
Total & 128 & 60.98 & 15.63 \\
\hline
\end{tabular}

Likewise, as shown in Table 7, the mean scores of the general chemistry exam achievement for low achievers, moderate achievers, and high achievers were 53.17, 59.38, and 73.14 respectively. The standard deviations of these levels were also found to be $11.92,15.16$, and 13.28 respectively.

Table 7. Descriptive Statistics for General Chemistry Exam Achievement Score According to Student' Achievement Levels

\begin{tabular}{lccc}
\hline Achievement levels & $\mathbf{N}$ & Mean & SD \\
\hline Low-achievers & 38 & 53.17 & 11.92 \\
Moderate-achievers & 58 & 59.38 & 15.16 \\
High-achievers & 32 & 73.14 & 13.28 \\
Total & 128 & 60.98 & 15.63 \\
\hline
\end{tabular}

Based on the results of two-way analysis of variance (ANOVA) conducted in order to determine whether general chemistry exam achievement of freshman engineering students differ statistically in terms of the teaching method and achievement level factors, it was found that there were statistically significant mean differences in students' general chemistry exam achievement with respect to both achievement level $(\mathrm{F}(2,122)=22.38, \mathrm{p}=.000)$ and the interaction between teaching method and achievement level $(\mathrm{F}(2,122)=3.62, \mathrm{p}=.030)$ at the 0.05 significance level as shown in Table 8. It was implied that the magnitude of the effect size was large for the achievement level factor and medium for the interaction effect factor, and $26.8 \%$ and $5.6 \%$ of the total variance on general chemistry exam achievement were associated with those factors respectively (Cohen, 1988). As a result, there were both statistical significance and practical significance. Nevertheless, results of analysis of variance showed no statistically significant difference $(\mathrm{F}(1,122)=3.56, \mathrm{p}=.062)$ for the teaching method factor.

Table 8. Two-way ANOVA Results of General Chemistry Exam Achievement with Teaching Method and Achievement Level Factors

\begin{tabular}{lcccccc}
\hline Source & $\begin{array}{c}\text { Sum of } \\
\text { Squares }\end{array}$ & df & $\begin{array}{c}\text { Mean } \\
\text { Square }\end{array}$ & F & p & $\begin{array}{c}\text { Partial } \\
\boldsymbol{\eta}^{2}\end{array}$ \\
\hline Teaching method & 628.76 & 1 & 628.76 & 3.56 & .062 & .028 \\
Achievement level & 7912.69 & 2 & 3956.34 & 22.38 & .000 & .268 \\
Teaching method*Achievement level & 1280.69 & 2 & 640.35 & 3.62 & .030 & .056 \\
\hline
\end{tabular}


Since general chemistry exam achievements of engineering students trained based on the traditional teaching and PLTL model were influenced by the achievement level of the students as indicated in Figure 3 , it can be misleading to interpret the main effects of factors from the result of the two-way ANOVA in Table 8 (Pallant, 2011). This interaction was also indicated in Figure 3. Thus, simple main effects were examined by using the oneway ANOVA technique whether teaching method factor differed statistically for the low, moderate, and high level of achievement groups. Descriptive and inferential statistical results were presented in Table 9 and Table 10 , respectively.

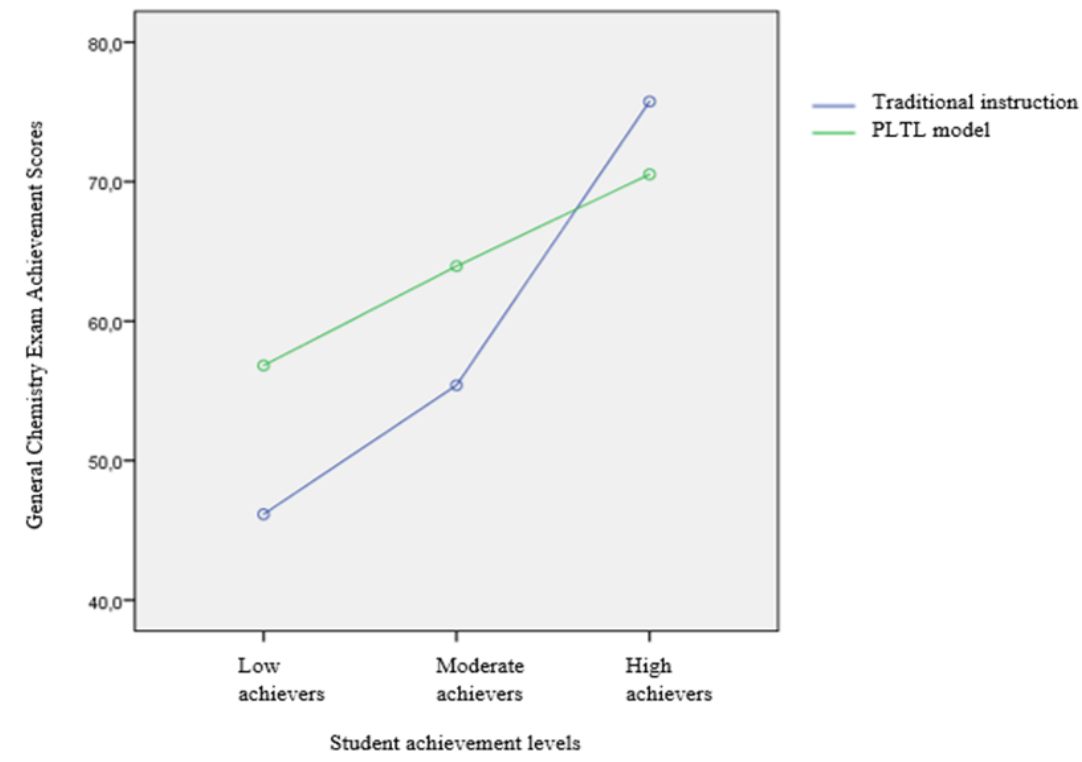

Figure 3. Line Graph Showing the Interaction of Subgroups of Achievement Level Factor with Teaching Method

According to the one way ANOVA results in Table 10, firstly there was a statistically significant difference between the teaching methods for the low achievers' group $[\mathrm{F}(1,36)=8.18, \mathrm{p}=.007]$. As seen from Table 9, general chemistry exam achievement mean score of engineering students with low level of achievement instructed by PLTL model $(\mathrm{M}=56.82, \mathrm{SD}=10.91)$ were higher than those of engineering students with low level of achievement instructed by traditional instruction $(M=46.15, S D=10.89)$. Secondly, there was a statistically significant difference with regard to the traditional instruction and PLTL models for the moderate achievers [F (1, $56)=4.90, \mathrm{p}=.080]$. Therefore, moderate achievers who were trained with PLTL model $(\mathrm{M}=63.94, \mathrm{SD}=16.32)$ were more successful in the general chemistry exam than those who were trained with traditional teaching method $(M=55.40, S D=13.06)$. Finally, there was no statistically significant mean difference in general chemistry exam achievement score between PLTL group and traditional group with high level of achievement $[\mathrm{F}(1,30)=1.25, \mathrm{p}$ $=.273]$.

Table 9. Descriptive Statistics Results of General Chemistry Exam Achievement in terms of Students' Achievement Levels and Teaching Method.

\begin{tabular}{lllcccc}
\hline Achievement levels & Teaching methods & N & Mean & SD & Minimum & Maximum \\
\hline Low-achievers & Traditional & 13 & 46.15 & 10.89 & 29.0 & 62.0 \\
& PLTL & 25 & 56.82 & 10.91 & 37.0 & 84.5 \\
\multirow{4}{*}{ Moderate-achievers } & Total & 38 & 53.17 & 11.92 & 29.0 & 84.5 \\
& Traditional & 31 & 55.40 & 13.06 & 31.5 & 84.0 \\
& PLTL & 27 & 63.94 & 16.32 & 24.0 & 92.5 \\
High-achievers & Total & 58 & 59.38 & 15.16 & 24.0 & 92.5 \\
& Traditional & 16 & 75.75 & 12.72 & 54.5 & 91.0 \\
& PLTL & 16 & 70.53 & 13.72 & 46.5 & 93.0 \\
& Total & 32 & 73.14 & 13.28 & 46.5 & 93.0 \\
\hline
\end{tabular}


Consequently, it was determined that for the low and moderate achievers, the general chemistry exam achievement grades were better when they were taught with the PLTL model rather than traditional teaching but the teaching methods applied for the high achievers did not make any difference in that.

Table 10. One-Way ANOVA Results of General Chemistry Exam Achievement by Students' Success Level

\begin{tabular}{llcccccc}
\hline Achievement levels & Source & $\begin{array}{c}\text { Sum of } \\
\text { Squares }\end{array}$ & $\mathbf{d f}$ & $\begin{array}{c}\text { Mean } \\
\text { Square }\end{array}$ & $\mathbf{F}$ & $\mathbf{p}$ & $\boldsymbol{\eta}^{\mathbf{2}}$ \\
\hline Low-achievers & Between groups & 973.01 & 1 & 973.01 & 8.18 & .007 & .185 \\
& Within groups & 4280.63 & 36 & 118.91 & & & \\
Moderate-achievers & Total & 5253.64 & 37 & & & & \\
& Between groups & 1052.78 & 1 & 1052.78 & 4.90 & .031 & .080 \\
& Within groups & 12040.38 & 56 & 215.01 & & & \\
High-achievers & Total & 13093.16 & 57 & & & & \\
& Between groups & 217.88 & 1 & 217.88 & 1.25 & .273 & .040 \\
& Within groups & 5250.23 & 30 & 175.01 & & & \\
& Total & 5468.12 & 31 & & & & \\
\hline
\end{tabular}

The values of the eta squared ( $\eta 2)$ given in Table 10 indicated that the low-achievers group had a large effect size of 0.185 while the moderate-achievers group had a medium effect size of 0.08 (Cohen, 1988). In other words, the proportion of variance in general chemistry exam achievement scores explained by the treatment was $18.5 \%$ for the low-achievers and $8 \%$ for the moderate-achievers. These values of effect size pointed out that the differences arising from teaching methods had practical significance too. When examining the general chemistry exam achievement scores of high achievers, that was not statistically significant but also not practically significant due to its small effect size (Eta squared $=0.040)$.

\section{Discussion and Conclusion}

In conclusion, this study revealed how general chemistry exam achievement scores of engineering students with different achievement levels were influenced when traditional teaching and PLTL model were applied. The low and moderate achievers in PLTL group showed greater performance in general chemistry exam compared to those who received traditional instruction; however, it was found that there was no difference in general chemistry exam achievement scores of the high achievers with respect to the teaching methods. Based on these results, exam achievement of students with low and moderate level can be enhanced to a high level through PLTL model. These findings provided a different dimension to the results presented for the effectiveness of the model in the literature. When this model was continued through a sustainable mechanism, it can be argued that it will be probably observed a further increase in the exam achievement of the students. To illustrate, Lewis (2011) advocates that the PLTL model should be disseminated to different courses and subjects, not just one course in order to get more effective results. Similarly, Mitchell et al. (2012) find that the effect of PLTL on students' achievements in the following years is greater than the traditional instruction. Therefore, researchers suggest that these interventions should be disseminated at the curriculum level.

In this study, the treatment was effective in low-achievers and moderate-achievers, even though it was conducted biweekly. This work presents important results not only for chemistry educators but also for other field educators about supporting students with low achievement level in the STEM and similar courses. We can also say that active and collaborative models (Kuh, Cruce, Shoup, Kinzie, \& Gonyea, 2008; Pascarella \& Terenzini, 2005) are more effective to support meaningful learning compared to traditional teaching, based on the literature related to effective college science teaching. Under the guidance of peer leaders, the PLTL model supported students' learning processes by providing them the opportunity to work with teams. The details about the six key PLTL components prepared in coordination with the relevant literature on implementation guide for researchers planning similar research.

Among the reasons why low and moderate achievers benefit more from PLTL model may be to feel themselves belonging to a group. According to Snyder, Sloane, Dunk and Wiles (2016), students belonging to minority groups feel isolated and unhappy in the context which traditional methods were applied, and thus, their achievement may be lower. With group-oriented teaching methods, such students may feel to be more accessible to the learning of 
scientific concepts. For this reason, we can expect that the students who are in the lower group will attain a higher level of success through PLTL and other similar learning environments. This model can be used in a way of systematic, long-term and sustainable practices to prevent low- and middle-level students from leaving the school due to the failure.

The first thing related to the limitations of this study is the duration of the implementation. Because in the majority of the studies, the PLTL workshops were carried out once a week; however, in this study they were held biweekly. Another issue related to the duration is the fact that PLTL model was generally disseminated on the faculty basis, not limited to one semester. Nevertheless, the findings, which reported the difference in exam achievement of moderate- and low-achieving students, were the desired result. The high achievers may have felt that the group members were slowing themselves down. In addition, the random assignment of the experimental and control groups rather than the random sampling of the students for each group is a common problem for most quasi-experimental studies. This can be a problem for the external validity of the results. The findings of the study can be generalized to the students in the research environment in which the treatment was conducted. The factors that threaten internal validity may fall within the limitations of the study. Researchers tried to control such threats at the highest level.

To summarize, PLTL has been extensively applied in our country for the first time in higher education. This study offered a compelling evidence on the benefits of PLTL model about the supporting low and moderate achievers in the research context

\section{Acknowledgments}

*This study is a part of the first author's doctoral dissertation.

*We would like to express our sincere thanks and gratitude to CEAC Faculty Members, Head of the Department, Prof. Şeniz Özalp-Yaman and each team leader for their continued great support throughout the PLTL project. 


\section{Akran-Liderliğinde Takım Öğrenmesi Modelinin Üniversite Öğrencilerinin Genel Kimya Sınav Başarısı Üzerindeki Etkisinin İncelenmesi}

\section{Giriş}

Üniversite öğrencileri arasında ilk yıllarda okulu terk etme oranı oldukça yüksektir (Barefoot, 2004) ve bu durumun en önemli nedenlerinden birisi de başarısızlıktır (Şimşek, 2013). Kişisel etmenlerin yanı sıra okul etmenleri (Peters, 1992) başarısızlığı dolayısı ile dersleri ve okulu bırakma oranlarını artırmaktadır. Bu durum fen teknoloji mühendislik ve matematik (FeTeMM) gibi üniversite birinci sınıf giriş derslerinde başarıyı engelleyen kilit unsurlar arasındadır. Bu nedenle, bu gibi derslerde öğrenci başarı, ilgi ve aidiyeti gibi değerleri artırma potansiyeline sahip kapsamlı programlara odaklanmak gerekmektedir. Tinto (1975) e göre bunu yapmanın bir yolu, öğrencilerde akademik bir topluma aidiyet duygusu hissedeceği öğretim modelleri geliştirmektir. Bunun yanında Tobias (1992) 'a göre, mentörluk ilişkileri öğrencilerin başarı ve kariyerlerinde kritik önem taşımaktadır ve geleneksel öğretim yaklaşımları bu özelliklerin vurgulanması açısından başarısızdır. Geleneksel öğretim, bilimsel sorgulamaların ön bilgi üzerine inşa edilmesini ve bu sorgulamaların güçlü münazara ve tartı̧̧malar ile geliştirilmesi hususunda eksik kalmaktadır. Bu bağlamda Akran Liderliğinde Takım Öğrenmesi (ALTÖ) FeTeMM alanlarında yaygın olarak kabul gören ve uygulamaları olan bir öğretim modeli olmuştur. ALTÖ, yukarıda bahsedilen sorunların üstesinden gelebilecek bir model olarak algılanmaktadır çünkü bu uygulamalarda öğrenciler bilimsel tartı̧̧malara aktif katılım gösterirler. Bu durum öğrencilerin öğrenmesi dolayısı ile başarıları ile yakından ilişskilidir.

\section{Akran Liderliğinde Takım Öğrenmesi (ALTÖ)}

ALTÖ modeli, ilk olarak 1990'ların başında New York Şehir Koleji'nde (CCNY) Genel Kimya dersinde David Gosser tarafından tanıtıldı ve Ulusal Bilim Vakfi'nın (NSF) desteğiyle Amerika Birleşik Devletleri'ndeki pek çok kolejde ve üniversitede kimya, biyoloji, fizik, matematik ve bilgisayar bilimleri ile mühendislik derslerinde öğrenci öğrenmesi ve yüksek yıpratma oranlarıyla ilgili fakülte kaygılarını gidermek amaçıla uygulandı ve yaygınlaştırıldı (Gafney \& Varma-Nelson, 2008; Goodwin, 2002).

ALTÖ modeli, dersi veren öğretim elamanın derste hem genel rutinlerini hem de öğretim yöntemlerini değiştirmelerini gerektirmez. Varma-Nelson (2006, s.19)' da 'ALTÖ modeli'nin dersi aynen koruduğunu ve haftalık 2 saatlik çalıştayla yeni bir yapı oluşturduğunu belirtmektedir. Ayrıca, konunun özü iyi organize edilmiş ve destekleyici çalışma gruplarıdır bu nedenle, dersin bir saatinin bu akran liderliğinde çalıştay ile yer değiştirilmesi önerilir (Gafney \& Varma-Nelson, 2008). Böylece, ALTÖ modeli, bir aktif öğrenme ortamında ders konularına uygun olarak bir dizi takım çalışmasına uygun olarak geliştirilmiş problemleri tartışmak ve çözmek için bir akran liderin rehberliğinde altı ya da sekiz öğrenciden oluşan kü̧̈ük bir grubun haftada bir araya geldiği yapılandırılmış bir takım öğrenme biçimi olarak tanımlanabilir (Gafney \& Varma-Nelson, 2008; Varma-Nelson, Cracolice \& Gosser, 2004). Bu modelin bir diğer özelliği ise, hem kimyada hem de iletişimde yetkin bir akran liderinin özel rolüdür. Genel olarak dersi yakın zamanda başarılı (A veya B) ile bir şekilde tamamlamış ve liderlik potansiyeli ile güçlü iletişim becerileri gösteren lisans öğrencileri arasından seçilir (Gafney \& Varma-Nelson, 2008). ALTÖ çalıştaylarda, öğrenciler problemin çözümü için birlikte çalışıllarken, akran liderde kullanılabilecek kaynaklar, düşünme şekilleri ve nasıl bir süreç izlemeleri hakkında tavsiyelerde bulunurlar (Crocolice \& Deming, 2001). Ayrıca, akran liderler, bir gruptaki öğrencilerin kendi aralarında etkileşime girerek tarışma başlatmalarını kolaylaştııır, beyin firtınası yapma ve yapılandırılmış sorunları çözme ve tartışma konularında da onları teşvik eder (Gosser ve diğerleri, 2001). Varma-Nelson ve Coppola'ya (2005) göre, öğrenciler tek bir doğru cevabıöğrenmek yerine ALTÖ çalıştaylarında çeşitli çözüm yolları bulmayı ve bunları değerlendirmeyi amaçladıklarından dolayı, öğrenciler veya liderler için cevap anahtarları verilmemelidir.

Dersi veren öğretim elamanın ALTÖ modelindeki rolü, ALTÖ çalıştay materyallerini hazırlamak ve akran liderleri seçmek ve dersleri için onları eğitmektir (Gosser ve diğerleri, 2001). Akran liderler, her hafta ders konusunu ve ALTÖ çalıştay materyallerini tartışmak için öğretim elamanıyla bir araya gelirler. Ayrıca, ALTÖ çalıştayının içeriği dersin haftalık konu programa paralel olmalıdır. Dahası, atölye materyalleri, sadece kavram yanılgılarını ele almak ve kimya kavramlarında kavramsal anlayış geliştirmek için değil, aynı zamanda gruplarda işbirliğini, etkileşimi, ve aktif katılımı teşvik etmek için dikkatli bir şekilde oluşturulmalıdır (Gosser \& Roth, 1998). Sonuç olarak, öğrenciler kavramsal öğrenmelerini geliştirebilir ve bilimsel fikirleri sosyal bir toplulukta tartışabilirler. (Gosser \& Roth, 1998; Gosser ve diğerleri, 1996; Sarquis ve diğerleri, 2001; Varma-Nelson ve diğerleri, 2004). 


\section{Kuramsal Arkaplan}

ALTÖ, öğrencilerin aktif katılımını vurgulayan sosyo-bilişsel kurama dayanmaktadır. Modelin arkasındaki kuramsal yaklaşım, Vygotsky'nin (1987) sosyal öğrenme kuramına dayanır. Model aynı zamanda yapılandırmacı yaklaşımın "öğrencilerin öğrenmesi bireysel ve toplumsal süreçler içindeki aktif rol almaları ile yapılanır" (Ulusal Araştırma Konseyi [National Research Council], 1996, s.28) ilkesine de dayanmaktadır. Driver, Newton ve Osborne (2000)'na göre bu modelde küçük takımlar, bireyler arasındaki sosyal süreçler aracılığı ile bilginin inşa edilmesine aracı olan bilimsel topluluklardır. ALTÖ çalıştayları da buna benzer topluluklar olarak öğrencilere aktif ve işbirlikçi öğrenme ortamı sunarak tartışma, uzlaşma, bilgiyi inşa etme, anladıklarını sunma ve akranlarının bakış açılarını duyma firsatı verir. Problemleri çözerken öğrencilerin birbirleri ile etkileşimleri fikirlerin paylaşılmasını, değerlendirilmesini ve rafine edilmesini sağlarken bu yolla her birey deneyimlerini kullanışlı bilgiye dönüştürür (Brown ve Campione, 1994; Brown, Collins \& Duguid, 1991; Roschelle, 1992). Sinıf ortamında kavramsal öğrenme "kişinin başkaları ile iletişim kurma yolu ile bilgiyi sosyal süreçler üzerinden kurma ve onu yeniden oluşturma olanağına bağımlıdır " (Driver ve diğerleri, 2000, s. 298). Kısacası bilgiyi anlama başkaları ile iletişim ve etkileşim kurarak gelişir, bu nedenle bilginin sosyal süreçler vasitası ile oluşturulduğu görüşüne dayanan öğretim modelleri geniş uygulama olanağı bulur (Brown ve diğerleri, 1991). ALTÖ de bu modellerden biri olarak "bilgiyi paylaşmak", "açıklığa kavuşturmak" ve "bilgiyi akranlara yaymak" gibi akran etkileşimlerine imkân sağlar (Rivard \& Straw, 2000, s.585). Bu modelde gözlemlenen bir başka anahtar süreç de öğrenci tartışmalarında gözlemlenen "bağlı söylem" (connected discourse) yani öğrencilerin fikir alışverişlerinin ayrıntılarının neden olduğu karmaşık akıl yürütme sürecidir. Akran liderli öğrenme ortamının sunduğu bu ve benzeri süreçler bilginin anlamlı bir şekilde yapılanmasına zemin hazırlama potansiyeline sahiptir.

Öğrenci merkezli birçok öğrenme ortamının temel unsuru, bir akran tarafından öğrenci etkileşiminin kolaylaştırılıp, desteklenmesidir. Bu öğrenme ortamı bireyin yakınsal gelişim düzeyini aşmasını hedefler. Sosyal öğrenme kuramcısı Vygotsky'ye göre (1978, s.86), yakınsal gelişim bölgesi "kişinin bağımsız bir şekilde problem çözme durumunun ortaya koyduğu mevcut gelişim düzeyi ile daha yetkin akranlarla işbirliği ya da yetişkinlerin rehberliğinde problem çözme ile gelebileceği olası gelişim düzeyi arasındaki uzaklık” olarak tanımlanır. Öğrenci merkezli yaklaşımların olumlu bir başka yanı da öğrencilerin kavramsal olarak zengin olan ders materyalinin öğrenmesinde birbirlerine yardım ederek yakınsal gelişim alanını desteklemesidir. ALTÖ modelinde akran lider olan birey, dersin öğretim elemanına kıyasla öğrencilerin yakınsal gelişim düzeyine eşit ya da oldukça yakın olduğu için öğrencilerle etkileşime hocanın sahip olmadığı yollarla girme şansı bulur. Ayrıca, akranın ders ve içerik bilgisi ile ilgili mevcut öğrenci de olmayan yoğun deneyimi, ona öğrencilerin karşılıklı etkileşim ve fikir alışverişini teşvik etmede kritik bir görev yükler. Bu görevi üstlenen akran lider takımındaki tüm öğrencilerin katılımını, desteklenmesini ve özerkliğini teşvik edecek şekilde çalışır.

ALTÖ modeli işbirlikli öğrenme modelinde olduğu gibi öğrencilerin ortak amaca ulaşmak için birlikte çalışması unsurlarını içerir (Johnson \& Johnson, 1999, 2009; Johnson, Johnson, \& Smith, 1991). Akran liderli takım öğrenmesi karşılıklı olumlu bağımlılık (positive interdependence) ve yüz yüze etkileşimi bütünleştirirken aynı zamanda daha bilgili ve deneyimli bir akran lider aracılığı ile küçük grup çalışmasını ve bireysel hesap verilebilirliği desteklemektedir. Öğrencilerin anladıklarını sınıf arkadaşlarına anlatabilmesi bireysel hesap verilebilirlik olarak örneklendirilebilir. Bu model de öğrencilere temel becerilerin öğretilmesi formal işlemlerden ziyade süreç içerisindeki iletişim ve etkileşim yolu ile gelişir. Bunların ötesinde tüm öğrenciler; kadınlar, erkekler, azınlıklar, yabancı uyruklular makul bir biçimde işbirlikçi öğrenme ortamına katılabilir ve bu ortamdan faydalanabilir.

\section{Genel Kimya Dersinde ALTÖ Uygulamaları}

Araştırmalar öğrenci merkezli pedagojilerin öğrencilerin bağımlı öğrenme toplulukları oluşturmasına firsat sağladığı için klasik pedagojilerden öğrencilerin performanslarını artırma da daha etkili olduğunu göstermektedir (Irvine, Code \& Richards, 2013; Tutty \& Klein, 2008). Etkinliği yüksek olan bu öğretim modellerinden biri olan ALTÖ yaklaşımının öğrenciler, liderler, öğretim üyeleri ve kurumlar üzerinde etkinliği pek çok öğrenme ortamında ölçülmüş ve değerlendirilmiş (Ba'ez-Galib, Colon-Cruz, Resto, \& Rubin, 2005; Hockings, DeAngelis, \& Frey, 2008; Lewis \& Lewis, 2005; Lyon \& Lagowski, 2008; Tien, Roth, \& Kampmeier, 2002), pek çok FeTeMM disiplinlerinde başarılı olduğu ortaya konmuştur (Hockings ve diğerleri. 2008; Lewis 2011; Lyle \& Robinson 2003; Lyon \& Lagowski 2008; Preszler 2009; Tien ve diğerleri, 2002; Wamser 2006). ALTÖ konusu ilk kez kimya alanında uygulandığı için, yapılan çalışmaların çoğunluğu bu alanda özellikle genel kimya (Alger \& Bahi, 2004; Ba'ez-Galib ve diğerleri, 2005; Chan \& Bauer, 2015; Drane, Micari, \& Light, 2014; Hockings ve 
diğerleri, 2008; Mitchell, Ippolito, \& Lewis, 2012) ve organik kimya (Lyle \& Robinson, 2003; Tien ve diğerleri, 2002) derslerinde uygulanmakla birlikte biyoloji (Prezler, 2009), matematik ve mühendislik (Liou-Mark, Dreyfuss, \& Young, 2010; Loui-Mark \& Robbins, 2008) derslerinde de uygulandığı ve başarılı sonuçları olduğu belirlenmiştir. Diğer bir deyişle, ALTÖ grubu öğrencileri daha yüksek notlar almış (Hockings ve diğerleri, 2008) ve öğrenmeleri daha kalıcı olmuştur (Drane ve diğerleri, 2014; Lewis, 2011).

Ba'ez-Galib ve diğerleri (2005) Chem2Chem isimli etkileşimli bir program hazırlayarak lisans düzeyinde genel kimya öğrencilerinin başarılı olmalarını hedeflemiştir. Dersin kalitesinden, içerik ve beklentilerden ödün vermeden öğrencilere destekleyici bir öğrenme ortamı hazırlanmış, öğrencilerin olumlu çalışma tutumu ve özgüvenleri desteklenerek akademik ve duygusal ihtiyaçlar karşılanmıştır. Araştırmacılar geliştirdikleri bu programın öğrencilerin başarıları üzerinde çarpıcı sonuçları olduğunu vurgulamaktadır. Örneğin, 1995 ve 1997 yılları arasında (Chem-2-Chem den önce) öğrencilerin \% 42-51 başarısız olurken bu programdan sonra bu oran \% 21 e düşmüştür. Ayrıca, Hockings ve diğerleri (2008) ALTÖ modelini geleneksel ders yapısı yerine kullanmayı amaçlayarak öğrenci başarısı üzerinde etkisini incelemiştir. Sonuçlar modelin öğretim üyelerinin ve öğrencilerin ihtiyaçlarını karşıladığını, modelin dersin zorunlu bir parçası şeklinde sunulmasının geleneksel üniversite yapısına uyduğunu ve öğrencilerin zorunlu olarak katılım gösterdiğini ortaya çıkarmıştır. Genel kimya dersini 2. döneminde de ALTÖ modeli ile alan öğrencilerin performansları birinci dönem ALTÖ ye katılmayan öğrencilerle kıyaslandığında yaklaşık üçte birlik bir olumlu fark ortaya çıkmıştır. Mitchell ve diğerleri (2012)'de iki dönem süren genel kimya dersini ve ALTÖ'nün öğrencilerin ikinci dönemki kimya dersine devam kararlarını incelemiş, ve tek dönemlik uygulama ile öğrenci başarılarını arttıramadıklarını bulmuşlardır.

Yine kimya alanında yapılan çalışmaları incelediğimizde, Lewis ve lewis 2005 yılında lisans düzeyinde genel kimya dersinde akran liderli gruplar oluşturmuş, bu modelin öğrencilerin anlamalarını nasıl etkilediğini değerlendirmiştir. Deneysel bir çalışma yürüterek aynı öğretim elemanına ait bir grup deney grubunu oluştururken diğeri kontrol grubunu oluşturmuştur. Öğrencilerin ara sınav ve final sınavları notları karşılaştırıldığında akran liderli grup öğretiminin öğrencilerin performansları üzerinde anlamlı bir fark yarattığı ortaya çıkmıştır. Lewis (2011) başka bir çalışmasında tamamen ALTÖ modelini üniversite birinci sınıf öğrencilerinin genel kimya dersindeki performanslarını inceleyerek değerlendirmiştir. Normal ders süresini koruyarak, zamanın yaklaşık üçte birlik bir kısmında ALTÖ uygulanmış ve sonuçlar geleneksel öğretim yapan gruplarla karşılaştırılmıştır. İki grubun sonuçları karşılaştırıldığında, deney gruplarının geleneksel yöntemle ders işleyen gruplara göre istatistiksel anlamda \% 15 gibi anlamlı bir farkla gelişim gösterdikleri ortaya çıkmış ve konuların ileriki zamanlarda hatırlanma oranının deney gruplarında daha yüksek olduğu tespit edilmiştir. Ek olarak, araştırmacı ALTÖ gruplarındaki azınlık öğrencilerin, kontrol gruplarındaki azınlıklara göre dersi geçme oranlarının arttığını ortaya koymuştur. McCreary, Golde ve Koeske (2006) genel kimya dersinin laboratuarında uygulama yapmış, deney ve kontrol grubu oluşturarak ALTÖ nün etkinliği incelenmiştir. Gerek elde ettikleri nitel veriden gerekse öğrencilerin yazılı sınav cevaplarının içerik analizinden çalıştaylı yürüyen laboratuar öğrencileri diğer gruptan daha yüksek performans göstermiştir.

Amaral ve Vala (2009) lisans öğrencilerinin ilk dönem aldıkları genel kimya dersinde ALTÖ uygulaması yapmış, mentörlük (akran liderlik) yapan öğrenciler üzerinde uygulamanın etkisini, mentörlerin sonraki dönmelerde ki başarıları ve konuların hatırlanabilmesini incelemiştir. Mentörlük programına (eğitimine) katılmayan ve katılan ancak mentörlük yapmayan öğrencilerin performansları karşılaştırılmıştır. Birinci dönem genel kimya dersinde mentörlük programına katılan öğrencilerin diğer öğrencilere göre daha yüksek bir ortalamaya sahip oldukları, daha az çaba gösterdiği halde dersten çekilme oranlarının çok daha düşük olduğu belirlenmiştir. Gafney ve Varma-Nelson'nın (2007) yürüttüğü ALTÖ deneyiminin akran liderler üzerindeki uzun vadeli etkileriyle ilgili bir başka çalışmada, akran liderlerin hem kendi performansları geliştirdikleri hem de daha özgüvenli olma ve gelişmiş takım becerilerine sahip olmak gibi bazı kişisel kazanımlar elde etikleri rapor edilmiştir. Akran liderler üzerine yapılan başka bir çalışma da Schray, Russo, Egolf, Lademan, ve Gelormo (2009) tarafından yapılmıştır. Araştırmacılar önceki yıllardan seçilen öğrencilerin yaptığı akran liderliğin mi yoksa sınıf içinden seçilen akran liderlerin mi daha etkili olacağını incelemiş, sınıf içinden seçilen akran liderlerin önceki yıl dersi alan akran liderlerden farklı olmadığını ortaya çıkarmışlardır. Yazarlar iki farklı grubunda farklı bir rolü olduğu yorumlamış, standart akran liderlerin daha çok öğrettiğini ve gruplarını daha iyi kontrol ettiklerini ancak diğerleri ile arkadaş olmadıklarını, sınıf içinden seçilen liderlerin ise grup arkadaşlarını daha iyi tanıdıklarını belirtmiştir. İki farklı tip akran liderli grupların akademik performansları ve öğrenci memnuniyet düzeyleri karşılaştırıldığında her iki grubun tamamen eşit olduğunu ortaya koymuşlardır. Bir başka çalışmada Gosser (2011) tarafından yürütülmüş, ALTÖ çalıştaylarına katılan öğrencilerle katılmayan öğrencilerin notları karşılaştırılmıştır. 
Sonuçlar dersten C ve üstü not alan öğrencilerin yüzdesinin \% 15 ALTÖ çalıştayına katılan öğrencilerin lehine olduğunu göstermektedir.

Alan yazın özetinden anlaşıldı̆̆ üzere modelin öğrenci performansı üzerinde azımsanmayacak etkisi vardır. Ancak farklı başarı düzeyinde öğrencilerin ALTÖ modelinden yararlanması ile ilgili yeterince sonuç yoktur. Türkiye de bu konuda kapsamlı bir araştırma yapılmamış olması, öğrenciler üzerinde etkisinin bilinmemesi bu konuda bir araştırma yapılmasının cazibesini artırmaktadır. Bu bağlamda bu çalışmanın amacı bu modelin Türkiye bağlamında bir vakıf üniversitesinde mühendislik fakültesi birinci sınıf öğrencilerinin genel kimya dersindeki başarıları üzerinde etkisini incelemektir. Yöntemin özellikle farklı başarı gruplarındaki öğrencilerin başarısını nasıl etkilediği araştırılarak konunun alan yazınına katkıda bulunulacaktır. Temel araştırma sorusu, birinci sınıf mühendislik öğrencilerinin genel kimya alanındaki sınav başarısı üzerine öğretim yöntemlerinin (PLTL modeli ve Geleneksel öğretim) ve başarı düzeylerinin (düşük, orta ve yüksek) etkisi nedir. Alt sorular aşağıdaki gibidir.

1. ALTÖ modeli ve Geleneksel öğretim alan birinci sınıf mühendislik öğrencilerin Genel kimya sınav başarı notları arasında istatistiksel olarak anlamlı bir fark var mıdır?

2. Birinci sınıf mühendislik öğrencilerin başarı seviyelerinin (düşük, orta ve yüksek) Genel kimya sınav başarı notları üzerinde istatistiksel olarak anlamlı bir etkisi var mıdır?

3. Birinci sınıf mühendislik öğrencilerin başarı düzeylerinin Genel kimya sınav başarı notlarına etkisinde uygulanan öğretim yöntemine (ALTÖ modeli ve Geleneksel) göre istatistiksel olarak anlamlı bir fark var midir?

\section{Yöntem}

\section{Araştırma Deseni}

Bu çalışmanın amacı, lisans düzeyinde mühendislik öğrencilerinin aldığı genel kimya dersinde akran liderli takım çalışması yürüterek öğrencilerin akademik başarısı üzerine etkisini incelemektir. Deneysel araştırma tekniklerinden olan yarı-deneysel (quasi experimental) yöntem kullanılacaktır. Eğitim araştırmalarında genellikle çalışmanın yapılacağı kurumda sınıflar ya da öğrenciler rastgele seçilemediği için tam deneysel çalışma yapmak nerdeyse imkânsız denecek kadar zordur, bu nedenle eğitim de yapılan çoğu deneysel araştırma da yarı deneysel tasarım kullanılır (Fraenkel \& Wallen, 2006). Bu nedenle, mevcut çalışmada deney ve kontrol grupları, aynı profesörün verdiği dersin iki şubesinden rastgele seçilmiştir. Tablo 1' de görüldüğü gibi deney grubuna bir dönem boyunca akran liderliğinde takım öğrenmesi modeli uygulanırken kontrol grubunda geleneksel öğretim uygulanmış ve iki grupta aynı zamanda 2 ara sınava ve final sınavına girmişlerdir.

Tablo 2. Araştırma Deseni

\begin{tabular}{lcccccc}
\hline Gruplar & Uygulamalar & Ara-Sınav 1 & Uygulamalar & Ara-Sınav 2 & Uygulamalar & Final \\
\hline KG & GÖ & AS & GÖ & AS & GÖ & F \\
DG & ALTÖ & AS & ALTÖ & AS & ALTÖ & F \\
\hline
\end{tabular}

Not: DG: Deney grubu, KG: Kontrol grubu, ALTÖ: Akran liderli takım öğrenmesi, GÖ: Geleneksel öğretim, AS: Ara sinav, F: Final sinavi

\section{Örneklem}

Uygun örnekleme yöntemi ile seçilen çalışmanın örneklemini Atılım üniversitende 1.sınıf düzeyinde verilen ve mühendislik öğrencilerinin aldığı genel kimya (CEAC 105) dersine kayıtlı olan 128 kişi oluşturmaktadır. Aynı öğretim üyesi tarafindan verilen dersin kontrol grubunda (KG) 60 kişi (47'si erkek 13'ü kadın) bulunurken deney grubunda(DG) 68 kişi (53'ü erkek 15'i kadın) bulunmaktadır. Deney grubu öğrencileri, ALTÖ çalıştayının en az $50 \%$ sini katılan kişilerden oluşmaktadır. Öğrencilerin yaşı, ağırlıklı olarak 19 civarındadır. Her başarı düzeyindeki öğrenci sayısı da Tablo 2'de KG ve DG için ayrı ayrı verilmiştir.

Tablo 2. Geleneksel ve ALTÖ Modeline Göre Eğitim Alan Öğrencilerin Öğrenci Başarı Seviyeleri Açısından Frekans ve Yüzdelik Karşılaştırılması

\begin{tabular}{llll}
\hline Başarı düzeyleri & \multicolumn{2}{c}{ Öğretim yöntemleri } & Toplam \\
\hline & Geleneksel & ALTÖ & \\
\cline { 3 - 4 }
\end{tabular}




\begin{tabular}{lcccccc}
\hline & Sayı & Yüzde & Sayı & Yüzde & Sayı & Yüzde \\
\hline Düşük başarılılar & 13 & 21.8 & 25 & 36.8 & 38 & 29.7 \\
Orta başarılılar & 31 & 51.6 & 27 & 39.7 & 58 & 45.3 \\
Yüksek başarılılar & 16 & 26.6 & 16 & 23.6 & 32 & 25 \\
Toplam & 60 & 100 & 68 & 100 & 128 & 100 \\
\hline
\end{tabular}

Tablo 2' deki iki grubun toplam yüzde değerleri incelendiğinde en çok yığılmanın \% 45.3 ile "Orta başarılılar" kategorisinde ve ondan sonra \% 29.7 ile "Düşük başarılılar" kategorisinde ve onu takiben de \% 25 ile "Yüksek başarılılar" kategorisinde olduğu görülmüştür. Bu genel kalıp öğrenciler toplam olarak ele alındığında ve ALTÖ modelinde fark edilirken, geleneksel öğretimde yüksek başarılıların yüzdesi (26.6) düşük başarılıların yüzdesinden (21.8) daha fazla olduğu görülmektedir.

Ayrıca, daha önce Genel Kimya dersine devam etmiş ve başarılı bir şekilde tamamlayanlardan 14 öğrenci akran lider olarak seçilmiştir. Akran liderlerini seçmek için amaçlı örnekleme yöntemi kullanılmıştır, çünkü akran liderler ALTÖ modelinin doğru uygulanması için bazı gerekliliklere ve özelliklere sahip olmalıdır. Örneğin, liderler daha önce aldıkları bu derste başarılı öğrenciler (B notu veya daha iyi) olmalı ve liderlik, iletişim ve grup çalışmasında bazı becerilere sahip olmalıdırlar. Çalışmaya katılan öğrencilere ve liderlere gönüllü katılım onay ve bilgilendirilme formu uygulanmıştır.

\section{Veri Toplama Araçları}

Genel kimya sınav başarı notu. Öğrencilerin sınav notları bu çalışmada öğrencilerin genel kimya dersindeki başarılarını gösterecektir. Genel kimya dersinde, 20 sorudan oluşan çoktan seçmeli olarak hazırlanan ve dönem içerisinde yapılan 2 tane ara sınav ve aynı sekilde hazırlanan ve dönem sonunda yapılan 1 tane final sınavı vardır. Bu sinavlarda her doğru cevap 5 puan ve her yanlış cevap 0 puan olarak kabul edilir ve toplamda her öğrencinin alacağı not 0 ile 100 puan arasında değişir. İlaveten, bu sınavlardaki konu içeriklerine bakıldığında, Tablo 5 de gösterilen bölüm numaralarına göre 6, 7, 8, 9, 10 ara sınav I de; 11,12, 5,19 ara sınav II de ve yazılan bütün bölümler ise final sınavında çıkmıştır. Bu sınavlar, o dönem dersi veren öğretim üyeleri tarafından hep birlikte hazırlanır. Ayrıca, öğrencilerin toplam sınav başarı notları sınav puanlarına göre hesaplanmış ve bu sınavların yüzdeleri Tablo 3' te verilmiştir.

Tablo 3. Yapılan Sınavların Dönem Sonu Genel Kimya Notuna Yüzdelik Etkileri

\begin{tabular}{lc}
\hline Sinavlar & Not yüzdesi \\
\cline { 2 - 2 } Ara sinav I & $30 \%$ \\
Ara sinav II & $30 \%$ \\
Final sinavi & $40 \%$ \\
\hline
\end{tabular}

Öğrenci başarı düzeyleri (Üniversite yerleşme puanları-MF-4). 2011 - 2012 öğretim yılından itibaren geçerli olmak üzere Ölçme, Seçme ve Yerleştirme Merkezi (ÖSYM) tarafında her yıl yapılan sınav sistemi YGS (Yükseköğretime Geçiş Sınavı) ve LYS (Lisans Yerleştirme Sınavları) olarak iki adımda gerçekleşir. YGS tüm derslerin ortak müfredatı baz alınarak yapılan genel bir test iken LYS her dersin başarısını ölçmeye dayalı branş testleri topluluğudur. YGS'de YGS-1-2-3-4-5-6, LYS'de MF-1-2-3-4 (Matematik-Fen), TM-1-2-3 (TürkçeMatematik), TS-1-2 (Türkçe-Sosyal Bilimler) ve DİL-1-2-3 (Yabancı Dil) olmak üzere tam 12 ayrı puan türü bulunmaktadır. YGS ve LYS' de en düşük limit 100 en yüksek limit 500' dür. Mühendislik fakültesi bölümleri tercih ve yerleştirmelerde MF-4 puan türüne göre yerleşme yapılmaktadır. Öğrenci bu alandaki lisans programlarından birine yerleşmek için YGS, LYS-1 (Matematik) ve LYS-2 (Fizik, Kimya ve Biyoloji) sınavlarına girmesi gerekir. Daha sonra ÖSYM tarafından bu sınavlardan aldıkları puanlar ie MF-4 puanı hesaplanır. Genel kimya dersini alan öğrencilerin 2015-2016 öğretim yılı üniversite giriş puanları Atılım Üniversitesi öğrenci işleri biriminden sağlanmıştır. Öğrencilerin MF-4 puan aralığı 209 ile 390.65 arasındadır. Ortalama 295.10 civarında standart sapma is 39.75 olarak hesaplanmıştır. MF-4 puanları kategorik hale dönüştürülerek düşük, orta ve yüksek başarı seviyeleri oluşturulmuş ve Tablo 4' de frekans değerleri gösterilmiştir

Tablo 4. Öğrencilerin MF-4 Puan Türünün Kategorik Sınıflandırılması İle Oluşan Eklemeli Nispi Frekans Tablosu

\begin{tabular}{lccccc}
\hline Kategoriler & $\begin{array}{c}\text { AL-ÜL } \\
\text { (Not aralığı) }\end{array}$ & $\begin{array}{c}\text { Frekans } \\
(\mathbf{N})\end{array}$ & $\begin{array}{c}\text { Nispi Frekans } \\
(\boldsymbol{\%})\end{array}$ & $\begin{array}{c}\text { Eklemeli } \\
\text { Frekans (N) }\end{array}$ & $\begin{array}{c}\text { Eklemeli Nispi Frekans } \\
(\boldsymbol{\%})\end{array}$ \\
\hline Düşük Başarılılar & $<270.00$ & 46 & 36 & 46 & 36 \\
Orta Başarılılar & $270.00-319.99$ & 50 & 39 & 96 & 75 \\
Yüksek Başarılılar & $320.00>$ & 32 & 25 & 128 & 100 \\
\hline
\end{tabular}




\begin{tabular}{lll}
\hline Toplam & 128 & 100 \\
\hline
\end{tabular}

Not: AL: Alt limit, ÜL:Üst limit, N: Öğrenci sayısı.

\section{Uygulamalar}

\section{ALTÖ Modeli}

Bu kısımda deney grubunda 14 hafta boyunca yapılacak uygulama tanıtılmıştır. Bu uygulamada, iki hafta bir haftalık üç saat olan dersin bir saatlik kısmı alınarak toplamda 6 ALTÖ çalıştay düzenlenmiştir. Diğer haftalarda üç saatlik ders yapılmaya devam edilmiştir. Liderler akranlarıyla ALTÖ çalıştayı için belirlenen çalışma salonuna gelmiş ve sınıfın bir kısmında küme şeklinde bir oturma düzeni oluşturmuşlardır. ALTÖ çalıştaylarında liderler bir yaka kartı takmışlar ve akranlarına isimleri ile hitap etmişlerdir. Öğrenciler bu çalıştaylara daha önceden uygulama için hazırlanan ve onlara önceden verilen kitapçık ile katılmışlardır. İlk 10 dakikada akran liderler akranlarının daha önceden çözerek geldikleri kısım ile ilgili onların zorlandıkları yerleri belirlemişler ve konu hakkında bir özet yapılmıştır. Daha sonrasında kitapçıkta bulunan grup halinde çözülecek kısımla ilgili problemleri kendisine lider eğitimde anlatılan öğretme tekniklerini de kullanarak tartıştılar. Bu kısımda soruları çözmelerine ve analiz etmelerine süre tanınmış, ve daha sonra öğrencilere sorular sorup onları nasıl problemleri çözeceklerine dair ipuçlarıyla çözüme yönlendirmişlerdir. Birbirlerinden etkilenmeleri ve liderlerinin geri dönütleriyle kendi çıkarımlarında bulunmuşlardır. Verilen süre içerisinde problem çözümünün tüm akranlarca anlaşılıp anlaşılmadığ liderler tarafından kontrol edilmiştir. Problemler anlaşıldıktan sonra öğrencilere bireysel çözecekleri bir ya da iki sorudan oluşan bir test verilmiştir. Öğrenciler grup halinde takım sorularını tartıştıktan ve nasıl çözüleceğini öğrenmesinden dolayı bu soruları bireysel çözer duruma gelmiştir. Bu test değerlendirildikten sonra yapılamayan sorular o konunun iyi anlaşılamadığının bir kanıtı olarak alınmış ve böylece öğrencilere liderler tarafindan gerekli dönütler sağlanmıştır.

Uygulamanın uygunluğunu (fidelity) ve doğrulamasını (verification) artırmak için, ALTÖ grubunda yapılacak uygulama, alanyazın ve modelin teorik çerçevesi yardımıyla açıkça tanımlanmıştır. Bu nedenle, ALTÖ modeli'nin uygulanmasına ilişkin el kitabı (Gosser, al. 2001) kılavuz olarak ele alınmış ve Gafney tarafından önerilen altı kritik bileşen (Gafney \&Varma-Nelson, 2008) uygulamanın temeli olarak takip edilmiştir. ALTÖ modelinin bu altı kritik bileşeni olan bölüm desteği, dersin bileşeni olarak görülmesi, kurum içi/örgütsel düzenlemeler, idari destek, ders materyallerinin hazırlanması, akran liderlerin seçimi ve akran liderlerin eğitimi ilerleyen bölümlerde kısaca açıklanmıştır. Ayrıca, Şekil 1, uygulama öncesi ve uygulama sırasındaki bu bileşenleri içeren süreçleri toplu olarak göstermektedir. Bu bileşenler, ALTÖ modelinin tanımlanması, etkili uygulanması, değerlendirilmesi ve diğer ilişkili öğrenci merkezli metotlardan ayrılması açısından büyük önem taşımaktadır ve düzgün bir şekilde uygulananırsa, öğrenci performanslarında gözle görülür bir artış olması beklenmektedir. (Gafney ve VarmaNelson, 2008).

Bölüm desteğinin alınması. ALTÖ uygulamasının sorunsuz ilerlemesi için ilk adım bölüm desteğinin alınmasıdır. Bunun için genel kimya dersini veren Kimya Mühendisliği ve Uygulamalı Kimya Bölümü’nün öğretim üyeleri ve elemanları bilgilendirilmiş ve araştırma kapsamında yapılacak değişiklikler için destek verilmesi istenmiştir. Dersi verecek öğretim üyesi, özellikle uygulama boyunca ALTÖ çalıştayda gönüllü olarak işbirliği içerisinde olmuştur.

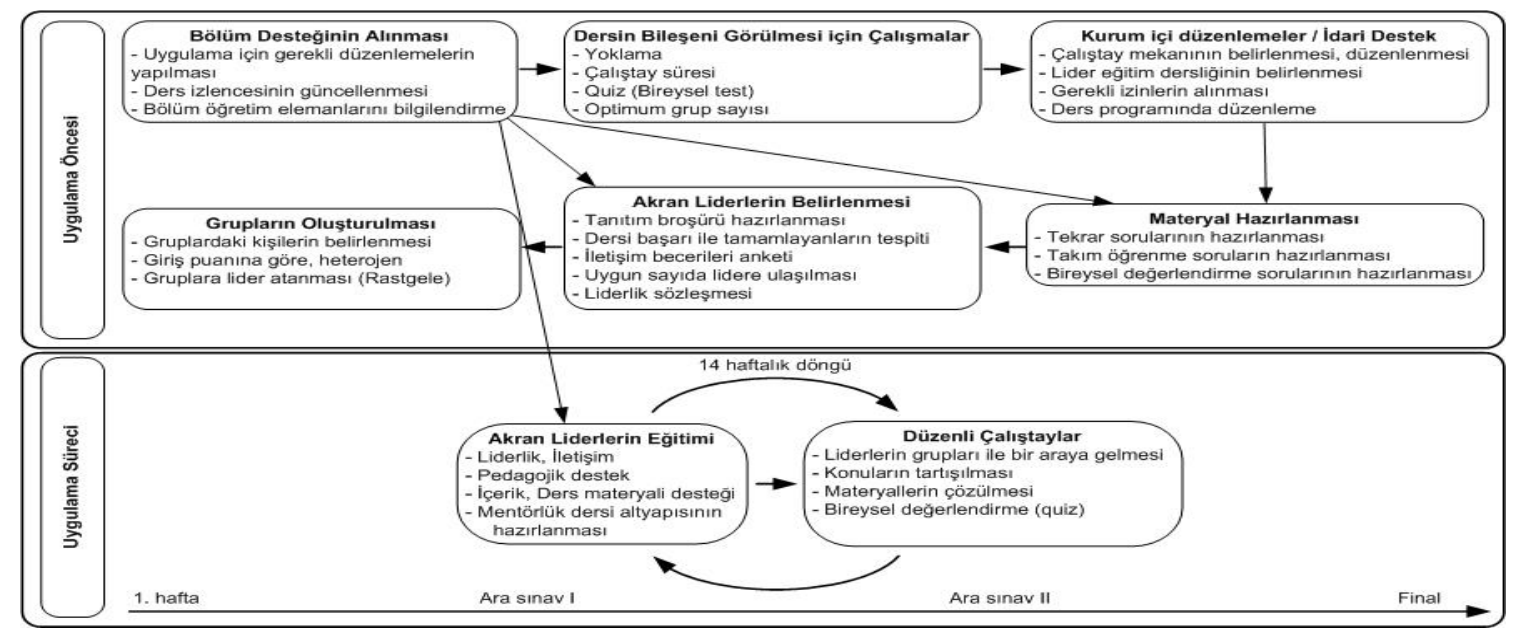


Bunun için, öğretim üyesi hazırlanan materyallerin içerikleri ders saatinde işlenen konularla örtüşmesi gerektiğinden materyalleri incelemeleri, dönüt vermeleri ve düzenlemeler yapılmasına destek vermiştir.

Dersin bileşeni görülmesi. Dersin diğer bileşenleri (teorik ders, laboratuar, problem çözme) gibi görülmesi ve diğerleri ile bütünleşmiş ve koordineli olması önemlidir. Bu nedenle de bu çalıştaylar öğrenciler için dersin diğer kısımları örneğin laboratuar gibi zorunlu olacaktır. ALTÖ çalıştaylarında bireysel olarak quizler yapılacak ve yoklamalar alınacaktır. Genel kimya dersinin haftalık ders süresi 50 dk lık 3 ders saatidir. Çalışma kapsamında dersin 50 dk 1 ders saatini alınıp ALTÖ çalıştayı olarak düzenlenmiştir. Gafney ve Varma-Nelson (2008) çalıştayın etkili olabilmesi için ideal sürenin 90 ile 120 dakika arasında olmasını söylemiştir. Bu nedenle 50 dk lık süre öğrencilerin programlarıyla çakışmayacak durumda $70 \mathrm{dk}$ çıkarılmıştır. ALTÖ çalıştayların içerikleri o haftaki teorik derste gördükleri konularla paralel olarak yürütülmüştür.

Kurum içi düzenlemeler ve idari destek. Haftalık ALTÖ çalıştaylarının aksamadan yürütülmesi için grup çalışmasına uygun ortamın oluşturulması ayrıca lider eğitimlerinin yapılacağı yerlerin tahsis edilmesi gerekmektedir. Bu nedenle, kampuste bu çalışmaya uygun olarak mühendislik fakültesi öğrenci çalışma salonu belirlenmiş ve idari birimden gerekli izinler alınmıştır. Ayrıca, gerekli olabilecek ek malzemeler masa, sandalye vb gibi öğrenci sayısına göre yeniden düzenlemeler yapılmıştır. Akran liderlerin eğitim saatlerinin ve ALTÖ çalıştayına katılım zamanlarının kendi ders programlarıyla çakışmayacak şekilde ayarlamalar yapılmıştır.

ALTÖ Çalıştay materyallerinin hazırlanması. Atılım Üniversitesinde Genel kimya (CEAC 105) dersi kimya mühendisliği ve uygulamalı kimya bölümü ve metalürji ve malzeme mühendisliği hariç diğer tüm mühendislik öğrencilerinin zorunlu olarak aldığ 5 AKTS kredili, haftalık 3 ders saati olan iki haftada bir de 3 saat laboratuarı olan bir derstir. Mühendislik öğrencileri bu dersi tek dönemde almaktadırlar. Dersin içeriği ve derste okutulan ders kitabındaki (Brown ve diğerleri, 2015) ilgili bölüm numaraları ve tahmini ders süresini gösteren bilgiler Tablo 5' de görülmektedir. Derste genel kimyanın seçili konuları işlenmektedir.

Uygulama başlamadan önce Tablo 5'de de bahsedilen her konu ile ilgili ALTÖ çalıştaylarında ders materyalleri dönem başında hazırlanmıştır. Bu süreçte, ALTÖ modelinde bahsedilen ve Gosser ve diğerleri (2001) tarafindan "ALTÖ Rehber Kitabı" da önerilen, ALTÖ çalıştaylarında kullanılan problemlerin öğrencileri uygun seviyede zorlaması, dersin içeriğine uygun olması ve aynı zamanda aktif ve işbirlikçi öğrenmeyi teşvik etmesi gibi noktalara uygunluğuna dikkat edilmiştir. Buna ek olarak, soruların oluşturulmasında Vygotsky (1987) tarafından önerilen "Yakınsal Gelişim Alanı" kavramı dikkate alınıp teorik çerçeve bu doğrultuda oluşturulmuştur. Bu doğrultuda ALTÖ çalıştayında kullanılmak üzere bir kitapçık hazırlanmış ve bu kitapçıkta her ünite içinde konu, konunun alt başlıkları ve ilgili kazanımlar bulunmaktadır.

Tablo 5. Genel Kimya 105 Ders Konulart ve Süreleri

\begin{tabular}{lcc}
\hline Ünite Numaraları & Konular & Tahmini Ders Süreleri \\
\hline 6 & Atomların Elektronik Yapısı & 7 \\
7 & Elementlerin Periyodik Özellikleri & 5 \\
8 & Kimyasal Bağların Temel Kavramları & 4 \\
9 & Molekül Geometrisi ve Bağlanma Teorileri & 3 \\
10 & Gazlar & 5 \\
11 & Sivılar ve Moleküller Arası Kuvvetler & 2 \\
\hline 5 & Katılar ve Modern Materyaller & 6 \\
19 & Termokimya & 5 \\
\hline
\end{tabular}

Ayrıca her ünitedeki ALTÖ çalıştay problemleri, Şekil 2 de gösterildiği gibi 3 bölümden oluşmaktadır: (1) Öğrencilerin çalıştaya katılmadan önce tamamlayacağı bir kendini-test-et kısmı, (2) Haftalık ALTÖ çalıştaylarında akran liderleri ile işbirliği içerisinde çözecekleri problemler, (3) Öğrencilerin anlamalarını test edecek ALTÖ çalıştayından sonra bireysel olarak çözecekleri alıştırmalar bulunmaktadır. Kendini test et bölümünde, o haftaki konuya ait özet niteliğinde öğrencilerin tek başlarına çözebilecekleri çoktan seçmeli problemlerle ön değerlenme yapılmıştır. Problemler, ALTÖ çalıştayına gelmeden önce öğrencilere verilip çözmeleri istenmiş ve bu çalıştaylarda da bu problemler hızlıca tekrar edilip grupça çözecekleri problemlere geçilmiştir. İşbirliği içerisinde çözecek ikinci bölümde, takım öğrenmesi problemleri konuya göre 3 yada 4 açık uçlu, akran lider yardımıyla çözülebilen ve takım çalışmasına uygun şekilde oluşturulmuş problemlerden oluşmaktadır. Böylelikle, akran 656 
liderlerin yardımı ve işbirlikçi çalışmalardan kaynaklı olan öğrenciler arasındaki sosyal etkileşim ile öğrencilerin potansiyelleri artırılmaya çalışılmıştır. Daha sonra, öğrencilere onların bireysel performanslarını değerlendirmek için takım öğrenmesi problemlerine benzeyen 1 ya da 2 sorudan oluşan bireysel olarak çözmeleri istenilen çoktan seçmeli yada açık uçlu problemler verilmiş̧ir. Öğrenciler grup çalışmasından sonra bu problemleri bireysel olarak çözebilmeleri beklenmektedir. Her öğrenci için yardım almadan bağımsız olarak problem çözme seviyesi ve sonrasında akran lider yardımı ile sosyal etkileşime girdikten sonra bireysel olarak problem çözebileceği seviye arasında ortaya çıkan fark öğrencinin yakınsal gelişim alanıdır. Sonuç olarak, ALTÖ modeli, öğrencilerin yakınsal gelişim alanını en iyi şekilde keşfetmelerini ve kullanmalarını sağlayacak materyalleri desteklediği çıkarsanabilir.

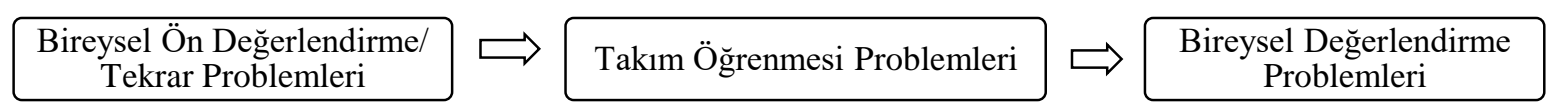

Şekil 4. ALTÖ Çalıştaydaki Problemlerin Bölümleri

Akran liderlerin belirlenmesi. Akran liderler gerek konu alan bilgisi gerekse liderlik özellikleri bakımından iyi eğitilmiş olmalıdır. Bu nedenle, akran lider adaylarının öncelikli olarak bir önceki dönem veya yıl genel kimya 105 dersini almış ve bu dersten ilk \% 20 lik dilimde bulunmuş olmaları beklenmiştir. Daha sonra, bu adaylarla görüş̧meler yapılmış ve iletişim becerileri de dikkate alınarak 14 akran lider seçilmiştir. Çalışmaya katılacak akran liderler belirlendikten sonra kendilerine aynen öğrencilerde olduğu gibi araştırmaya gönüllü katılım isteği formu uygulanmıştır.

Grupların oluşturulması. Verimli tartışmaların gerçekleşebilmesi için takımların büyüklüğünün ve çeşitliliğinin uygun olması gerekmektedir. Gafney ve Varma-Nelson (2008) 6 ile 8 kişi arasının bir takım için ideal olduğu belirtmişlerdir ve bu çalı̧şada ortalama grup büyüklüğü beş öğrencidir. Grupların birbirleriyle eşit olanaklara ve özelliklere sahip olmasını sağlamak için, gruplar oluşturulurken öğrencilerim cinsiyeti, başarı düzeyi ve bölümleri gibi bazı demografik bilgileri incelenmiştir. Örneğin, üniversiteye giriş puanları dikkate alınarak öğrenciler düşük orta ve yüksek başarı seviyesi olarak 3 gruba ayrılmış ve her takımda bu 3 seviyeden öğrenci olmasına dikkat edilmiştir. Ayrıca, gruplarda her bölümden öğrenci ve kız öğrenci olması sağlanarak heterojen bir yapı oluşturulmuştur. Her takıma liderler alfabetik isim sıralamasıyla rastgele atanmışıır.

Akran liderlerin eğitimi. Liderler ALTÖ çalıştaylarında soruları tarış̧madan önce iki hafta da bir düzenlen ve dönem boyunca sekiz defa yapılan 1,5 saatlik eğitim toplantılarına katılmışlardır. Bu eğitim boyunca Roth, Goldstein ve Marcus (2001) tarafindan yazılan "Akran Liderliğinde Takım Öğrenmesi: Akran Liderler El Kitabı" içersindeki konulara değinilmeye çalışılmıştır. Akran liderlere, "liderlik becerileri", "pedagojik destek" ve "ders materyalleri" olmak üzere 3 tema üzerine eğitim verilmiştir. Böylece, liderler eğitim için toplandıklarında o haftaki ders materyallerinin çözümüne ilişkin tartışma yapmalarının yanında pedagojik bilgiler ve sosyal iletişim ile ilgili bilgiler almışlardır.

Liderlik özellikleri ile ilgili kısımda, yönetim alanında uzmanlığı olan bir akademisyen, dönemin başında liderlere 2 saatlik bir eğitim verip, akranları ile nasıl iletişim kuracakları konusunda bilgilendirmede bulunmuştur. $\mathrm{Bu}$ eğitimin temel başlıkları; etkileyici konuşma ve ikna becerisi, dinleme becerisi, geri bildirimde bulunma becerisi, pozitif yaklaşımla iletişim kurma becerisi, iletişimde zamanlama becerisi, beden dilini etkili kullanma becerisiydi. Pedagojik destek teması altında ise araştırmacılar tarafından liderlere akranlarına nasıl yardım edecekleri ile ilgili her toplantıda kısa bilgiler verilmişstir. Bunlar, liderlerin rolü, öğrenme teorileri, öğrenme stilleri, soru sorma teknikleri, öğrencilerdeki öğrenme farklılıkları, motivasyon, herkese eşit firsatlar, ırk-sınıfcinsiyet, vb alt başlıklarıydı. Bunun yanında, sosyal yapılandırmacılık kuramı, çoklu zekâ kuramı, işbirlikçi öğrenme ve öğretme stratejileri bu toplantı saatlerinde konuşulmuştur. Liderlerin konunun doğasına ve grubundaki öğrencilerin ihtiyaçlarına göre uygun öğretme stratejisini seçip uygulaması beklenmiştir. Bununla birlikte, eğitimde akranlarına problem çözmenin aşamaları, akranlarına söz hakkı verme, zaman tanıma, ipuçları verme, düşük ve yüksek bilgi sahibi öğrencilerin ihtiyaçları arasında denge kurma gibi konulara ilişkin gerekli bilgiler sağlanmıştır. Ders materyalleri akran liderlerin eğitiminin önemli bir kısmını oluşturmuştur. ALTÖ Çalıştay süresince hangi kısma ne kadar vakit ayıracakları, öğrencilerin materyallerin çözümünde karşılaşacakları muhtemel güçlükler ve ihtiyaç duyduklarında başvurabilecekleri ekstra kaynaklar, materyallerin çözümüne dair tüm detaylar bu eğitimde tartışılmıştır. Akran liderlere ve öğrencilere ALTÖ modelinde de vurgulandığı gibi ALTÖ çalıştayındaki problemlerin cevap anahtarı verilmemiştir (Varma-Nelson \& Coppola, 2005). Liderlerin bu çalışmadaki rollerini iyi anlaması çok önemlidir çünkü ALTÖ çalıştaylarında birer öğretmen değil de daha çok rehber gibi davranmaları gerekmektedir. 


\section{Geleneksel Öğretim}

Kontrol grubundaki öğrenciler, 14 hafta boyunca aynı öğretim üyesi tarafından verilen genel kimyanın üç ders saatine girmişler ancak ALTÖ çalıştaylara katılmamışlardır. Deney grubunun ders saatinde de olduğu gibi aynı öğretim üyesi öncelikle o haftaki konunun kavramsal içeriğini tanıtmış ve daha sonra konuyla ilgili uygulamaya yönelik bazı soruları çözümlemişlerdir. Kontrol grubundaki ders süresinin üçte biri ALTÖ çalıştayına ayrılmadığından, öğretim üyesi bu grupta soruları çözecek daha çok zamana sahipti.

Ayrıca kontrol grubu ve deney grubu için ders saatlerinden bazıları gözlemlenmiş ve araştırmacılar tarafindan bazı alan notları alınmıştır. Derste, genellikle öğretim üyesi tarafından kavram açıklanarak tahtaya yazılmış, sonra kavramlarla ilgili problemleri kendisi tarafindan çözülmüş, daha sonra problemlerle ilgili birkaç soru sormuş ama bunları düşünmeye ve analiz etmeye zaman vermemiştir. Bazı öğrenciler kavram ve problemler ile ilgili notlar alırlarken, bazıları ise sadece dinledi. Bazı öğrenciler ie öğretim üyesi arasında arasında sorulan sorular doğrultusunda bazen tartışmalar olmuştur. Ancak öğrenciler genellikle pek soru sormadılar, ve kavram hakkında derin düşünmemişlerdir. Dersde kullanılan yöntem, temel olarak klasik anlatım, sorgulama ve bazen de birkaç öğrenci ile öğretmen arasındaki tartışmalardır. Bu nedenle, ağırlıklı olarak öğretmen merkezli olduğu sonucuna varılmıştır. Son olarak, geleneksel öğretimin, dersi veren öğretim elemanı tarafından çalışma sırasında amaçlandığı şekilde kullanıldığı sonucuna varılmıştır.

\section{Verilerin Analizi}

Çalışmadaki verilerin analizinde SPSS 24 paket programı kullanılmıştır. Veriler iki yönlü varyans analizi (twoway ANOVA) ile incelenmiştir. Bu analizin seçilmesinin nedeni iki bağımsız değişkenin (öğretim yöntemi ve başarı düzeyi) bir bağımlı değişken (genel kimya sınav başarı notu) üzerindeki etkisini ayrı ayrı test etmek yerine, faktörlerin temel etkilerini ve iki faktörün bağımlı değişken üzerindeki ortak etkisini eş zamanlı olarak test etmektir. Bu çalışmada istatiksel olarak anlamlı bir ortak etki bulunduğundan dolayı her başarı düzeyi için tek yönlü varyans analizi (one-way ANOVA) yapılarak basit temel etkiler verilmiştir. Verilerin analizi, varsayımları kontrol edilerek $95 \%$ güven aralığında yapılmıştır. Bu varsayımlar; verilerin bağımsız olması (bağımsızlık), bağımlı değişkenin sürekli ölçek olması ve bağımsız değişkenin bir grup değişkenine (categorical) sahip olması, grup içi dağılımların normal olması (within group normality) (normallik) ve varyansların homojenliği (homojenlik) dir.

\section{Bulgular}

Çalışmanın bulgular kısmında öğretim yöntemleri ve öğrenci başarı düzeylerine göre genel kimya sınav başarı notu betimsel istatistiklerine, iki yönlü ANOVA ile öğretim yöntemi ve başarı düzeyi faktörlerinin öğrencilerin genel kimya sınav başarısı üzerindeki bireysel temel etkilerini ya da ortak etkisini istatiksel olarak anlamlı bir şekilde açıklayıp açıklamadığına ve tek yönlü varyans analizi ile öğrencilerin genel kimya sınav başarı puanlarının gruplarda uygulanan öğretim yöntemlerine göre öğrenci başarı seviyeleri açısından farklılaşıp farklılaşmadığına yer verilmiştir.

Çalışmaya katılan birinci sınıf mühendislik öğrencilerinin genel kimya sınav başarı puanlarının öğretim yöntemi ve başarı düzeylerine göre ortalama ve standart sapma değerleri Tablo 6 ve Tablo 7'da yer almaktadır. Tablo 6'den görülebileceği gibi öğretim yöntemi değişkenine göre, geleneksel öğretim ve ALTÖ modeliyle eğitim alan öğrenciler için genel kimya sınav başarı ortalama puanları sırasıyla 58.83 ve 62.88 olarak hesaplanırken standart sapma değerlerinin sırasıyla 16.47 ve 14.71 olduğu görülmüştür.

Tablo 3. Öğretim Yöntemlerine Göre Genel Kimya Sınav Başarı Notu Betimsel İstatistik Sonuçları

\begin{tabular}{lccc}
\hline Öğretim yöntemleri & $\mathbf{N}$ & $\overline{\boldsymbol{X}}$ & $\mathbf{S S}$ \\
\hline Geleneksel & 60 & 58.83 & 16.47 \\
ALTÖ & 68 & 62.88 & 14.71 \\
Toplam & 128 & 60.98 & 15.63 \\
\hline
\end{tabular}

Benzer şekilde Tablo 7'de gösterildiği gibi düşük başarı, orta başarı ve yüksek başarı düzeyine sahip öğrencilerin genel kimya sınav başarı ortalamaları sırasıyla 53.17, 59.38 ve 73.14 'tür. Bu düzeylerin standart sapma değerleri ise sırasıyla $11.92,15.16$ ve 13.28 olarak bulunmuştur.

Tablo 4. Öğrenci Başarı Seviyelerine Göre Genel Kimya Sınav Başarı Notu Betimsel İstatistik Sonuçları

\begin{tabular}{cccc}
\hline Başarı düzeyleri & $\mathbf{N}$ & $\overline{\boldsymbol{X}}$ & $\mathbf{S S}$ \\
\hline Düşük başarılılar & 38 & 53.17 & 11.92 \\
658 & & &
\end{tabular}




\begin{tabular}{lccc}
\hline & & & \\
Orta başarılılar & 58 & 59.38 & 15.16 \\
Yüksek başarılılar & 32 & 73.14 & 13.28 \\
Toplam & 128 & 60.98 & 15.63 \\
\hline
\end{tabular}

Mühendislik fakültesi birinci sınıf öğrencilerinin genel kimya sınav başarılarının öğretim yöntemi ve başarı düzeyi faktörlerine göre istatistiksel olarak farklılık gösterip göstermediğini ortaya koymak amacıyla yapılan iki yönlü varyans analizine (two-way ANOVA) göre, Tablo 8' de gösterildiği gibi hem başarı düzeyi ( $\mathrm{F}(2$, $122)=22.38, p=.000)$ hem de öğretim yöntemi ve başarı düzeyi arasındaki etkileşimin $(F(2,122)=3.62, p=.030)$ öğrencilerinin genel kimya sınav başarılarının 0,05' lik anlamlılık düzeyinde istatistiksel olarak anlamlı bir farklılık olduğu bulunmuştur. Hesaplanan etki büyüklüğünün, başarı düzeyi faktörü için büyük (large) ve ortak etki faktörü için orta (medium) olduğu ve bu faktörlerin toplam varyansın sırasıyla \% 26.8 ve \%5.6'ini açıkladığ görülmektedir (Cohen, 1988). Sonuç olarak, hem istatistiksel olarak anlamlılık hem de pratikte anlamlılık söz konusudur. Buna rağmen, varyans analizi sonuçları öğretim yöntemi faktörüne göre istatistiksel olarak önemli bir farkın olmadığını göstermiştir $(\mathrm{F}(1,122)=3.56, \mathrm{p}=.062)$.

Tablo 5. Öğretim Yöntemi ve Başarı Düzeyi Faktörlerini İçeren Genel Kimya Sınav Başarılarıyla İlgili İki Yönlü ANOVA Sonuçları

\begin{tabular}{|c|c|c|c|c|c|c|}
\hline Kaynak & KT & sd & KO & $\mathbf{F}$ & p & KIsmi $\eta^{2}$ \\
\hline Öğretim yöntemi & 628.76 & 1 & 628.76 & 3.56 & .062 & .028 \\
\hline Başarı düzeyi & 7912.69 & 2 & 3956.34 & 22.38 & .000 & .268 \\
\hline Öğretim yöntemi*başarı düzeyi & 1280.69 & 2 & 640.35 & 3.62 & .030 & .056 \\
\hline
\end{tabular}

Geleneksel öğretim ve ALTÖ modeline göre eğitim alan mühendislik öğrencilerinin genel kimya sınav başarıları Şekil 3 'te de gösterildigi gibi öğrenci başarı düzeyleri değişkeninden etkilediğinden dolayı, faktörlerin temel etkilerini Tablo 8' deki iki yönlü anova sonucundan yorumlamak yanıltıcı olabilir (Pallant, 2011). Bu nedenle, düşük başarılılar, orta başarılılar ve yüksek başarılılar için öğretim yöntemlerinin istatistiksel olarak anlamlı düzeyde farklılaşıp farklılaşmadı̆̆ı ayrı ayrı tek yönlü anova tekniğiyle analiz edilerek basit temel etkileri incelenmiştir. Betimsel ve yordamsal istatistik sonuçları sırasıyla Tablo 9 ve Tablo 10’ da sunulmuştur.

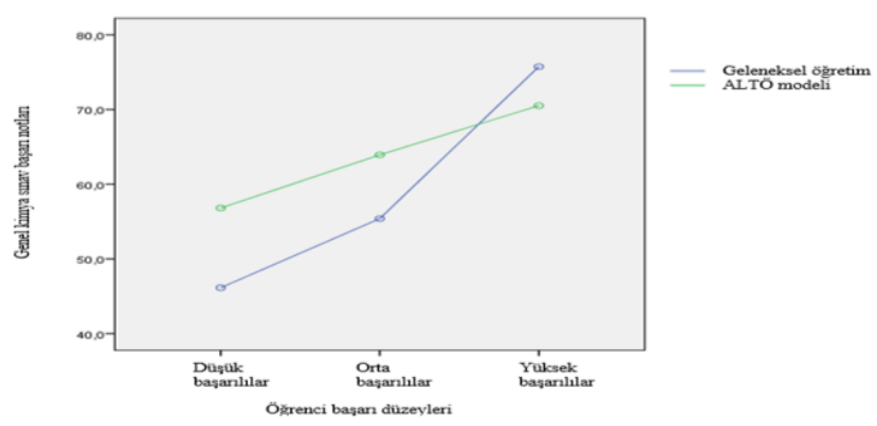

Şekil 5. Öğretim Yöntemi ile Başarı Düzeyi Faktörlünün Alt Gruplarının Etkileşimini Gösteren Çizgi Grafiği

Tablo 10’ daki tek yönlü ANOVA sonuçlarına göre, ilk olarak düşük başarılı grup için öğretim yöntemleri arasında istatistiksel olarak anlamlı bir fark bulunmuştur [ $F(1,36)=8.18, p=.007]$. Tablo 9' dan da görüldüğü gibi, ALTÖ modeline göre eğitim alan düşük başarı düzeyine sahip mühendislik fakültesi öğrencilerinin $(\mathrm{M}=$ 56.82, SS = 10.91) genel kimya sınav başarı notları geleneksel eğitim alan düşük başarı düzeyine sahip mühendislik fakültesi öğrencilerinden ( $\mathrm{M}=46.15, \mathrm{SS}=10.89)$ daha yüksektir. İkinci olarak, orta başarı düzeyine sahip öğrenci grubu için geleneksel ve ALTÖ modeline göre eğitim almaları açısından istatistiksel olarak anlamlı bir fark bulunmuştur [ $\mathrm{F}(1,56)=4.90, \mathrm{p}=.080]$. Dolayısıyla, orta başarı düzeyine sahip öğrencilerden ALTÖ modeline göre eğitim alanlar $(\mathrm{M}=63.94, \mathrm{SS}=16.32)$ geleneksel öğretim yöntemine göre eğitim alan öğrencilerden ( $\mathrm{M}=55.40, \mathrm{SS}=13.06)$ genel kimya sınavında daha başarılı olmuşlardır. Son olarak, yüksek başarı düzeyine sahip öğrencilerin geleneksel ve ALTÖ modeline göre eğitim alan iki grubu arasında genel kimya sınav başarı notlarında istatistiksel olarak anlamlı bir fark gözlenmemiştir [ $\mathrm{F}(1,30)=1.25, \mathrm{p}=.273]$.

Tablo 6. Öğrenci Başarı Seviyeleri ve Öğretim Yöntemine Göre Genel Kimya Sınav Başarı Notu Betimsel İstatistik Sonuçları

\begin{tabular}{lllllll}
\hline Başarı düzeyleri & Öğretim yöntemleri & N & X & SS & Minimum & Maksimum \\
\hline
\end{tabular}




\begin{tabular}{lllllll}
\hline Düşük başarılılar & Geleneksel & 13 & 46.15 & 10.89 & 29.0 & 62.0 \\
& ALTÖ & 25 & 56.82 & 10.91 & 37.0 & 84.5 \\
& Toplam & 38 & 53.17 & 11.92 & 29.0 & 84.5 \\
Orta başarılılar & Geleneksel & 31 & 55.40 & 13.06 & 31.5 & 84.0 \\
& ALTÖ & 27 & 63.94 & 16.32 & 24.0 & 92.5 \\
& Toplam & 58 & 59.38 & 15.16 & 24.0 & 92.5 \\
Yüksek başarılılar & Geleneksel & 16 & 75.75 & 12.72 & 54.5 & 91.0 \\
& ALTÖ & 16 & 70.53 & 13.72 & 46.5 & 93.0 \\
& Toplam & 32 & 73.14 & 13.28 & 46.5 & 93.0 \\
\hline
\end{tabular}

Sonuç olarak, düşük ve orta düzey başarılı öğrencilerin ALTÖ modeliyle öğretim aldıklarında geleneksel öğretim alan gruba göre genel kimya sınav başarı notlarının daha iyi olduğu, ancak yüksek başarılı öğrenciler için uygulanılan öğretim yöntemlerinin bir fark oluşturmadığı belirlenmiştir.

Tablo 7. Öğrencilerin Başarı Düzeyine Göre Genel Kimya Sınav Başarılarıyla İlgili Tek Yönlü ANOVA Sonuçları

\begin{tabular}{|c|c|c|c|c|c|c|c|}
\hline Başarı düzeyleri & Kaynak & KT & sd & KO & $\mathbf{F}$ & $\mathbf{p}$ & $\eta^{2}$ \\
\hline \multirow[t]{3}{*}{ Düşük başarılılar } & Gruplar aras1 & 973.01 & 1 & 973.01 & 8.18 & .007 & .185 \\
\hline & Grup içi & 4280.63 & 36 & 118.91 & & & \\
\hline & Toplam & 5253.64 & 37 & & & & \\
\hline \multirow[t]{3}{*}{ Orta başarılılar } & Gruplar arası & 1052.78 & 1 & 1052.78 & 4.90 & .031 & .080 \\
\hline & Grup içi & 12040.38 & 56 & 215.01 & & & \\
\hline & Toplam & 13093.16 & 57 & & & & \\
\hline \multirow[t]{3}{*}{ Yüksek başarılılar } & Gruplar arası & 217.88 & 1 & 217.88 & 1.25 & .273 & .040 \\
\hline & Grup içi & 5250.23 & 30 & 175.01 & & & \\
\hline & Toplam & 5468.12 & 31 & & & & \\
\hline
\end{tabular}

Tablo 10'da verilen eta kare ( $\eta 2$ ) değeri, düşük başarı gösteren grup 0.185 ile büyük etki büyüklüğüne sahipken orta başarı gösteren grubun 0.08 ile orta etki büyüklüğüne sahip olduğunu göstermektedir (Cohen, 1988). Diğer bir deyişle, uygulama tarafindan açıklanan genel kimya sınav başarı notlarındaki varyansın oranı, düşük başarılılar için $\% 18.5$ ve orta düzey başarılılar için $\% 8$ olduğu görülmektedir. Etki büyüklüklerinin bu değerleri öğretim yöntemlerinden kaynaklı farklılıkların pratik anlamlılık taşıdığı da görülmektedir. Yüksek başarı düzeyinde olan grubun genel kimya sınav başarı notları incelendiğinde istatistiksel olarak anlamlı olmamanın yanında küçük etki büyüklüğüne sahip olduğundan dolayı hem de pratikte anlamlı olmadığı görülmektedir (Eta kare $=0.040$ ).

\section{Tartışma ve Sonuç}

Sonuç olarak, bu çalışma farklı başarı seviyelerindeki mühendislik fakültesi öğrencilerinin ALTÖ modeli ve geleneksel öğretim uygulandığında genel kimya başarı notlarını nasıl etkilendiğini ortaya çıkarmıştır. ALTÖ modeliyle öğretim alan düşük ve orta başarı düzeyindeki öğrenciler geleneksel öğretim alan öğrencilere kıyasla genel kimya sınav başarı notlarının daha yüksek olduğu, ancak başarı düzeyleri yüksek olan öğrencilerin uygulanılan öğretim yöntemlerine göre sınav başarılarında bir farklılığının olmadığı belirlenmiştir. Bu sonuçları temel alarak, ALTÖ modeli ile öğretim yapıldığında başarı düzeyleri düşük ve orta olan öğrenci gruplarını daha üst başarı seviyelerine çekebileceğimizi söyleyebiliriz. Bu bulgular alanyazında modelin etkinliğine yönelik sunulan bulgulara farklı bir boyut kazandırmıştır. Bu modelin sürdürülebilir bir mekanizma ile devamlılı̆̆ı sağlandığında, muhtemelen alan yazının iddia ettiği gibi de öğrencilerin sınav başarılarında daha fazla bir artış gözlemlenebileceği de savunulabilir. Örneğin, Lewis (2011)' de daha etkili sonuçlar elde edebilmek için sadece bir ders ile değil ALTÖ modelinin farklı derslere yaygınlaştırılması gerektiğini savunmuştur. Benzer şekilde, Mitchell ve arkadaşları (2012) da takip eden dönemlerdeki ALTÖ uygulamalarının öğrencilerin başarıları üzerinde etkisinin geleneksel öğretime kıyasla daha iyi olduğunu ortaya çıkarmışlardır. Bu nedenle, araştırmacılar bu uygulamaların müfredat düzeyinde yaygınlaştırılması gerektiğini önermektedir.

Bu çalışmada uygulama iki haftada bir olacak şekilde bir döneme yayılmış olmasına rağmen düşük ve orta başarı seviyeli öğrencilerde etkili olmuştur. Bu çalışmanın ortaya koydukları sadece kimya eğitimcileri için değil, FeTeMM ve benzeri derslerde başarı düzeyi düşük öğrencilerin desteklenmesi konusunda diğer alan eğitimcileri için de önemli sonuçlar sunmaktadır. Bunların ötesinde etkin üniversite öğretimi ile ilgili alan yazına dayanarak aktif ve işbirlikçi modellerin (Kuh, Cruce, Shoup, Kinzie, \& Gonyea, 2008; Pascarella \& Terenzini, 2005) geleneksel öğretime göre anlamlı öğrenmeyi daha fazla desteklediğini bu çalışma için de söyleyebiliriz. ALTÖ ortamı akran liderler rehberliğinde öğrencilerin takım halinde çalışmalarına firsat sunarak öğrenme süreçlerinde 
destek olmuştur. Uygulama ile ilgili alanyazına eşgüdümlü olarak hazırlanan altı temel ALTÖ bileşenine yönelik detaylar, benzer araştırmalar planlayan araştırmacılara yol gösterici niteliktedir.

Düşük ve orta başarı düzeyindeki öğrencilerin ALTÖ uygulamalarından daha fazla istifade etme nedenleri arasında kendilerini bir gruba ait hissetmeleri olabilir. Snyder, Sloane, Dunk ve Wiles'a (2016) göre azınlık gruplarına ait öğrenciler geleneksel yöntemlerin uygulandığı ortamlarda kendilerini izole ve mutsuz hissederler ve bu nedenle başarıları daha düşük olabilir. Grup çalışması odaklı öğretim yöntemleriyle bu gibi öğrenciler bilimsel kavramların öğrenmesinin daha erişilebilir olduğunu hissedebilirler. Bu nedenle, ALTÖ ve benzeri öğrenme ortamlarında daha alt grupta olan öğrencilerin daha yüksek seviyede başarı elde etmelerini bekleyebiliriz. $\mathrm{Bu}$ model sistematik, uzun dönemli ve sürdürülebilir uygulamalarla düşük ve orta başarı seviyeli öğrencilerin başarısızlıktan dolayı okulu terk etmelerini engelleme amaçlı kullanılabilir.

$\mathrm{Bu}$ çalışmanın sınırlılıkları ile ilgili olarak en başta sunulacak faktör araştırmanın süresidir. Çünkü uygulamaların çoğunda ALTÖ çalıştayları haftalık olarak yürütülmüştür, bu araştırmada ALTÖ oturumları iki haftada da bir kez düzenlenmiştir. Süre ile ilgili başka bir mevzu da uygulamaların bir dönemle sınırlı kalmayıp fakülte temelinde yaygınlaştırılmasıdır. Buna rağmen, bulguların orta ve düşük başarı düzeyindeki öğrencilerin sınav başarılarında fark yarattığını göstermesi istendik bir sonuçtur. Başarı düzeyleri yüksek olan öğrenciler ise grup üyelerinin kendilerini yavaşlattığını hissetmiş olabilir. Ayrıca, deney ve kontrol gruplarını rastlantısal bir şekilde oluşturulamaması bunun yerine rastlantısal atanması çoğu yarı-deneysel çalışma için ortak sorundur. Bu durum sonuçların genellenebilirliği ile ilgili sorunlara neden olabilir. Elde edilen bulgular uygulamanın yapıldığı araştırma ortamındaki öğrencilere genellenebilir. İç geçerliliği tehdit eden unsurlarda çalışmanın sınırlılıklarına girebilir. Araştırmacılar ilgili tehditleri en yüksek derecede kontrol altına almaya çalışmışlardır.

Özetlemek gerekirse ALTÖ ülkemizde kapsamlı bir şekilde yükseköğretimde ilk kez uygulanmıştır. Bu çalışma, araştırma bağlamında düşük ve orta düzeyde başarı gösteren öğrencileri destekleme konusunda ALTÖ modelinin yararları hususunda çarpıcı kanıtlar sunmuştur.

\section{Teşekkür ve Bilgilendirme}

*Bu araştırma, birinci yazarın doktora tez çalışmasından üretilmiştir.

*ALTÖ projesi boyunca devam eden büyük katkılarından ötürü, CEAC Öğretim Üyelerine, Bölüm Başkanı'na, Prof. Dr. Şeniz Özalp Yaman’a ve her takım liderine içten teşekkürlerimizi ve şükranlarımızı sunarız.

\section{References}

Alger, T. D., \& Bahi, S. (2004). An experiment in improving scores on ACS course-specific examinations at Southern Utah University. Progressions: the PLTL Project Newsletter, 5(2), 7-10.

Amaral, K. E., \& Vala, M. (2009). What teaching teaches: Mentoring and the achievement gains of mentors. Journal of Chemical Education, 86, 630-633.

Báez-Galib, R., Colón-Cruz, H., Resto, W., \& Rubin, M. (2005). Chem-2-chem: A one-to-one supportive learning environment for chemistry. Journal of Chemical Education, 82, 1859-1863. 
Barefoot, B. O. (2004). Higher education's revolving door: Confronting the problem of student drop out in US colleges and universities. Open Learning: The Journal of Open, Distance and e-Learning, 19(1), 9-18.

Brown, A.L., \& Campione, J.C. (1994). Guided discovery in a community of learners. In McGilly K. (Ed.), Classroom lessons: Integrating cognitive theory and classroom practice (pp. 229-270). Cambridge, MA: MIT Press.

Brown, J.S., Collins, A., \& Duguid, P. (1991). Situated cognition and the culture of learning. In Yazdani M. \& Lawler R.W. (Eds.), Artificial intelligence and education (Vol. 2). Norwood, NJ: Ablex.

Brown, T.L., LeMay, H.E. Jr., Bursten, B.E., Murphy, C.J., Woodard, P.M., \& Stoltzfus, M.W. (2015). Chemistry: The central science (13th ed.). Upper Saddle River, NJ: Pearson Education.

Chan, J.Y.K., \& Bauer, C.F. (2015). Effect of peer-led team learning (PLTL) on student achievement, attitude, and self-concept in college general chemistry in randomized and quasi-experimental designs. Journal of Research in Science Teaching, 52(3), 319-346.

Cohen, J. (1988). Statistical power analysis for the behavioral sciences (2nd ed.). Hillsdale, NJ: Erlbaum.

Cracolice, M. S., \& Deming, J. (2001). Peer-led team learning. Science Teacher, 68(1), 20-25

Drane, D., Micari, M., \& Light, G. (2014). Students as teachers: effectiveness of a peer-led STEM learning programme over 10 years. Educational Research and Evaluation, 20(3), 210-230.

Driver, R., Newton, P., \& Osborne, J. (2000). Establishing the norms of scientific argumentation in classrooms. Science Education, 84(3), 287-312.

Fraenkel, J. R., \& Wallen, N. E. (2006). How to design and evaluate research in education (6th ed). Boston: McGraw-Hill.

Gafney, L., \& Varma-Nelson, P. (2007). Evaluating peer-led team learning: A study of long-term effects on former workshop peer leaders. Journal of Chemical Education, 84(3), 535-539.

Gafney, L., \& Varma-Nelson, P. (2008). Innovations in science education and technology: Vol. 16. Peer-led team learning: Evaluation, dissemination, and institutionalization of a college level initiative. Weston, MA: Springer.

Gosser Jr, D. K., (2011). The PLTL boost: A critical review of research. Progressions: The PLTL Project Newsletter, 14(1). Retrieved from, https://docs.google.com/document/d/1ePcy1C8Rh1hizySbWG3xxeetuC4U-61myZyPikDZxo/edit?authkey=CM2GuN4L\&hl=en_US\&pli=1.

Gosser, D. K., Cracolice, M. S., Kampmeier, J. A., Roth, V. Strozak, V.S., \& Varma-Nelson, P. (2001). Peer-led team learning: A guidebook. Upper Saddle River, NJ: Prentice Hall.

Gosser, D. K., \& Roth, V. (1998). The workshop chemistry project: Peer-led team learning. Journal of Chemical Education, 75(2), 185-187.

Gosser, D.K., Roth, V., Gafney, L., Kampmeier, J. A., Strozak, V., Varma-Nelson, P., Radel S., \& Weiner, M. (1996). Workshop chemistry: Overcoming the barriers to student success. The Chemical Educator, 1(1), 1-17.

Hockings, S.C., DeAngelis, K.A., \& Frey, R.F. (2008). Peer-led team learning in general chemistry: Implementation and evaluation. Journal of Chemical Education, 85(7), 990-996.

Irvine, V., Code, J., \& Richards, L. (2013). Realigning higher education for the 21 st-century learner through multiaccess learning. Journal of Online Learning and Teaching, 9(2), 172-186.

Johnson, D. W., \& Johnson, R. T. (1999). Making cooperative learning work. Theory into practice, 38(2), 67-73.

Johnson, D. W., \& Johnson, R. T. (2009). An educational psychology success story: Social interdependence theory and cooperative learning. Educational Researcher, 38(5), 365-379.

Johnson, D.W., Johnson, R. T., \& Smith, K. A. (1991). Active learning: Cooperation in the college classroom. Edina, MN: Interaction Book Company.

Kuh, G. D., Cruce, T. M., Shoup, R., Kinzie, J., \& Gonyea, R. M. (2008). Unmasking the effects of student 662 
engagement on first-year college grades and persistence. Journal of Higher Education, 79(5), 540-563.

Lewis, S. E. (2011). Retention and reform: An evaluation of peer-led team learning. Journal of Chemical Education, 88(6), 703-707.

Lewis, S. E., \& Lewis, J. E. (2005). Departing from lectures: An evaluation of a peer-led guided inquiry alternative. Journal of Chemical Education, 82(1), 135-139.

Liou-Mark, J., Dreyfuss, A. E., \& Young, L. (2010). Peer assisted learning workshops in pre-calculus: An approach to increasing student success. Mathematics and Computer Education, 44(3), 249-259.

Loui-Mark, J., \& Robbins, B., (2008). Work-in-progress assessment of peer-led team learning in an engineering course for freshmen. Presented at the 38th ASEE/IEEE Frontiers in Education Conference 22-25 October 2008, Saratoga Springs, NY.

Lyle, K.S., \& Robinson, W.R. (2003). A statistical evaluation: peer-led team learning in an organic chemistry course. Journal of Chemical Education, 80(2), 132-134.

Lyon, D. C., \& Lagowski, J. J. (2008). Effectiveness of facilitating small-group learning in large lecture classes: A general chemistry case study. Journal of Chemical Education, 85(11), 1571-1576.

McCeary, C.L., Golde, M.F., \& Koeske, R. (2006). Peer instruction in general chemistry laboratory: Assessment of student learning. Journal of Chemical Education 83(5), 804-810.

Mitchell, Y. D., Ippolito, J., \& Lewis, S. E. (2012). Evaluating peer-led team learning across the two-semester general chemistry sequence. Chemistry Education Research and Practice, 13(3), 378-383.

National Research Council. (1996). From analysis to action: Undergraduate education in science, mathematics, engineering, and technology. Washington, DC: National Academy Press.

Pallant, J. (2011). SPSS survival manual: A step by step guide to data analysis using SPSS (4th ed.). Crows Nest, NSW: Allen \& Unwin.

Pascarella, E. T., \& Terenzini, P. T. (2005). How college affects students: A third decade of research (Vol. 2). San Francisco: Jossey-Bass.

Peters, O. (1992). Some observations on dropping out in distance education. Distance Education, 13(2), 234-269.

Preszler, R.W. (2009). Replacing lecture with peer-led workshops improves student learning. Life Sciences Education, 8(3), 182-192.

Rivard, L.P., \& Straw, S.B. (2000). The effect of talk and writing on learning science: An exploratory study. Science Education, 84(5), 566-593.

Roschelle, J. (1992). Learning by collaborating: Convergent conceptual change. Journal of Learning Sciences, 2(3), 235-276.

Roth, V., Goldstein, E., \& Marcus, G. (Eds.). (2001). Peer-led team learning: A handbook for team leaders. Upper Saddle River, NJ: Prentice Hall.

Sarquis, J. L., Dixon, L. J., Gosser, D. K., Kampmeier, J. A., Roth, V., Strozak, V. S., \& Varma-Nelson, P. (2001). The workshop project: Peer-led team learning in chemistry. In J. E. Miller, J. E. Groccia, \& M. Miller (Eds.), Student-assisted teaching: A guide to faculty-student teamwork (pp. 150-155), Anker Publishing Company: Bolton, MA.

Schray, K., Russo, M.J., Egolf, R., Lademan, W. \& Gelormo, D. (2009). Are in-class peer leaders effective in the peer-led team learning approach? Journal of College Science Teaching, 38(4), 62-67

Snyder, J. J., Sloane, J. D., Dunk, R. D. P., \& Wiles, J. R. (2016). Peer-led team learning helps minority students succeed, PLoS Biology, 14(3): e1002398. Retrieved from https://doi.org/10.1371/journal.pbio.1002398

Şimşek, H. (2013). Üniversite öğrencilerinin okulu bırakma eğilimleri ve nedenleri [University students' tendencies toward and reasons behind dropout]. Kuramsal Eğitimbilim Dergisi, 6(2), 242-271. Retrieved from http://dergipark.gov.tr/akukeg/issue/29349/314064. 
Tien, L. T., Roth, V., \& Kampmeier, J. A. (2002). Implementation of a peer-led team learning instructional approach in an undergraduate organic chemistry course. Journal of Research in Science Teaching, 39(7), 606632.

Tinto, V. (1975). Dropout from higher education: A theoretical synthesis of recent research. Review of Educational Research, 45(1), 89-125.

Tobias, S. (1992). Revitalizing college education. Tucson: Research Corporation.

Tutty, J., \& Klein, J. (2008). Computer-mediated instruction: A comparison of online and face-to-face collaboration. Educational Technology Research and Development, 56(2), 101-124.

Varma-Nelson, P., \& Coppola, B. P. (2005). Team learning. In N. J. Pienta, M. M. Cooper, \& T. J. Greenbowe, (Eds.) Chemists' guide to effective teaching: Volume I. Upper Saddle River. NJ: Pearson.

Varma-Nelson, P. (2006). Peer-led team learning. Metropolitan Universities, 17(4), 19-29.

Vygotsky, L.S. (1987). Mind in society: The development of higher psychological processes. Harvard University Press.

Wamser, C. C. (2006). Peer-led team learning in organic chemistry: Effects of student performance, success, and persistence in the course. Journal of Chemical Education, 83(10), 1562-1566. 